\title{
Central Role of Fibroblast $\alpha 3$ Nicotinic Acetylcholine Receptor in Mediating Cutaneous Effects of Nicotine
}

\author{
Juan Arredondo, Leon L. Hall, Assane Ndoye, Vu Thuong Nguyen, \\ Alexander I. Chernyavsky, Dani Bercovich, Avi Orr-Urtreger, Arthur L. Beaudet, and \\ Sergei A. Grando
}

Department of Dermatology (JA, LLH, AN, VTN, AIC, SAG), University of California at Davis, School of Medicine, Davis, California; Department of Molecular and Human Genetics (DB, ALB), Baylor College of Medicine, Houston, Texas; and Department of Molecular Genetics (DB), Migal-Galilee Technology Center, Tel Aviv Sourasky Medical Center, and Genetic Institute (AO-U), Tel Aviv University, Tel Aviv, Israel

\begin{abstract}
SUMMARY: Smoking is associated with aberrant cutaneous tissue remodeling, such as precocious skin aging and impaired wound healing. The mechanism is not fully understood. Dermal fibroblasts (DF) are the primary cellular component of the dermis and may provide a target for pathobiologic effects of tobacco products. The purpose of this study was to characterize a mechanism of nicotine (Nic) effects on the growth and tissue remodeling function of DF. We hypothesized that the effects of Nic on DF result from its binding to specific nicotinic acetylcholine receptors ( $\mathrm{nAChRs)}$ expressed by these cells and that downstream signaling from the receptors alters normal cell functioning, leading to changes in skin homeostasis. Using RT-PCR and Western blotting, we found that a 24-hour exposure of human DF to $10 \mu \mathrm{M}$ Nic causes a 1.9- to 28-fold increase of the mRNA and protein levels of the cell cycle regulators p21, cyclin D1, Ki-67, and PCNA and a 1.7- to 2-fold increase of the apoptosis regulators Bcl-2 and caspase 3. Nic exposure also up-regulated expression of the dermal matrix proteins collagen type $\mid \alpha 1$ and elastin as well as matrix metalloproteinase-1. Mecamylamine (Mec), the specific antagonist of nAChRs, abolished Nic-induced alterations, indicating that they resulted from a pharmacologic stimulation of nAChRs expressed by DF. To establish the relevance of these findings to a specific nicotinergic pathway, we studied human DF transfected with anti- $\alpha 3$ antisense oligonucleotides and murine DF from $\alpha 3$ nAChR knockout mice. In both cases, lack of $\alpha 3$ was associated with alterations in fibroblast growth and function that were opposite to those observed in DF treated with Nic, suggesting that the nicotinic effects on DF were mostly mediated by $\alpha 3$ nAChR. In addition to $\alpha 3$, the nAChR subunits detected in human DF were $\alpha 5, \alpha 7, \beta 2$, and $\beta 4$. The exposure of DF to Nic altered the relative amounts of each of these subunits, leading to reciprocal changes in $\left[{ }^{3} \mathrm{H}\right]$ epibatidine-binding kinetics. Thus, some of the pathobiologic effects of tobacco products on extracellular matrix turnover in the skin may stem from Nic-induced alterations in the physiologic control of the unfolding of the genetically determined program of growth and the tissue remodeling function of DF as well as alterations in the structure and function of fibroblast nAChRs. (Lab Invest 2003, 83:207-225).
\end{abstract}

\begin{abstract}
T n recent years, epidemiologic studies have 1 pointed to a significant correlation between cigarette smoke and alterations in the process of tissue remodeling, such as delayed and abnormal wound healing (Frick and Seals, 1994; Kwiatkowski et al, 1996; Silverstein, 1992), premature skin aging (Aizen and Gilhar, 2001; Ernster et al, 1995; Frances, 1998; Kadunce et al, 1991; Koh et al, 2002), and gingival recession and periodontitis (Haber, 1994; Qandil et al, 1997; Rota et al, 1999). The mechanism of compromised tissue response is not fully understood. Dermal fibroblasts (DF) are the primary cellular component of
\end{abstract}

\section{DOI: 10.1097/01.LAB.0000053917.46614.12}

Received September 4, 2002.

This work was supported by National Institutes of Health Grants AR42955, DE14173, and GM62136 and by research grants from Unilever Research-USA and the Flight Attendant Medical Research Institute (to $S A G$ ).

Address reprint requests to: Dr. S. A. Grando, Department of Dermatology, University of California Davis Medical Center, 4860 Y Street, Suite 3400, Sacramento, California 95817.E-mail: sagrando@ucdavis.edu the dermis and as such are the primary cell type determining skin texture and maintaining the dermal homeostasis. Experimental evidence implicates DF as having a major role in skin aging and wound healing (Grinnell, 1994; Kletsas et al, 2000; Lahmann et al, 2001b; Wokalek and Ruh, 1991; Yin et al, 2000, 2001), but the precise mechanisms of action of tobacco on DF remain unknown. Tobacco smoke contains at least 4000 chemicals, and it has been proposed that nicotine (Nic) is one of the key constituents causing adverse health effects (Benowitz, 1986, 1997; Benowitz and Gourlay, 1997; Macklin et al, 1998; Maus et al, 1998; Zevin et al, 1998). Nic is a likely mediator of pathobiologic effects of tobacco products in nonneuronal locations because it can activate specific cellsurface receptors expressed by nonneuronal cells. In addition to endothelial cells (Heeschen et al, 2001) and various types of human epithelial cells (Grando et al, 1995, 1996; Nguyen et al, 2000; Zia et al, 1997), classical neuronal-type nicotinic acetylcholine receptors (nAChRs) have been found on the surface of fibroblasts residing in the gingival (Hanes et al, 1991) 
and pulmonary (Sekhon et al, 1999) tissues. The nAChRs are classical representatives of a large superfamily of ligand-gated ion channel proteins, or ionotropic receptors, mediating the influx of $\mathrm{Na}^{+}$and $\mathrm{Ca}^{2+}$ and the efflux of $\mathrm{K}^{+}$(Steinbach, 1990). The heteromeric channels expressed in peripheral tissues can be composed of $\alpha 3, \alpha 5, \beta 2$, and $\beta 4$ (eg, $\alpha 3 \beta 2(\beta 4) \pm \alpha 5)$, and the homomeric channels can be made of several $\alpha 7, \alpha 8$, or $\alpha 9$ subunits. A heteromeric channel can be also made by a combination of $\alpha 9$ and $\alpha 10$ subunits (Elgoyhen et al, 2001).

Studies of the mechanisms of Nic action on various types of cells inhabiting mucocutaneous tissues have identified a number of biologic events mediated by a complex of genomic and nongenomic effects resulting from downstream signaling from the nAChRs ligated by Nic on the cell membrane (reviewed in Grando, 1997, 2001). Binding of Nic to nonneuronal cells results in changes in cell biology that include changes in viability and proliferation, differentiation, adherence, and motility, although the mechanisms of these alterations remain to be elucidated. In cardiac fibroblasts, for instance, direct pharmacologic effects of Nic include alterations in collagen gene expression, collagenase activity, and DNA synthesis (Tomek et al, 1994). In smooth muscle cells, Nic up-regulates expression of matrix metalloproteinases (MMPs)-zincbased proteinases involved in extracellular matrix degradation (Carty et al, 1996). Among up-regulated MMPs are collagenase-1 (MMP-1), gelatinase $A$ (MMP-2), and stromelysin-1 (MMP-3). Furthermore, it has been recently demonstrated that the acetylcholine (ACh)-gated ion channels, or nAChRs, expressed by nonneuronal cells not only mediate pharmacologic effects of $\mathrm{Nic}$ in these locations but also themselves provide a target for deleterious effects of Nic (Arredondo et al, 2001; Sekhon et al, 1999; Zia et al, 1997, 2000). Long-term exposures to Nic alter gene expression of nAChR subunits, which modifies the nicotinergic pharmacology of the exposed cells.

To gain a mechanistic insight into the mode of pathophysiologic action of Nic on the skin, we investigated the role of $\mathrm{Nic}$ in altering the normal physiology of DF. Our preliminary studies showed that exposure to Nic decreases proliferation of DF and increases their collagenase production, resulting in a net decrease in dermal matrix (Hall et al, 2000). We hypothesized that the effects of Nic on DF are mediated via its binding to specific $\mathrm{nAChRs}$ expressed on the fibroblast cell membrane and that this binding alters the normal functioning of the cholinergic system in DF, leading to changes in the normal skin homeostasis.

In this article, we describe the nAChR-mediated effects of Nic on the markers of fibroblast cell cycle progression and on the synthesis and degradation of dermal matrix components. Through RT-PCR and Western blotting (WB) we found that exposure of normal human DF to Nic increases the mRNA and protein levels of the cell cycle regulators p21, cyclin D1, Ki-67, PCNA and the apoptosis regulators Bcl-2 and caspase 3. Nic exposures also up-regulated expression of the dermal matrix proteins collagen type $\mid \alpha 1$ and elastin as well as MMP-1. To establish the relevance of these findings to a specific nicotinergic pathway operating in DF, we studied DF originating from knockout (KO) mice lacking $\alpha 3 \mathrm{nAChR}$. Lack of $\alpha 3$ was associated with alterations in fibroblast growth and function that were opposite to those observed in human DF exposed to Nic, suggesting that the Nic effects on DF are mostly mediated by activation of $\alpha 3$ nAChR. This hypothesis was corroborated by the ability to abolish Nic-induced changes in DF transfected with anti- $\alpha 3$ antisense oligonucleotide (AsOs) but not with control, sense oligonucleotide. Other nAChR subunits found to be expressed by human DF in vitro and in vivo were $\alpha 5, \alpha 7, \beta 2$, and $\beta 4$. Nic exposures altered the relative amounts of these subunits in DF, thus modifying the ligand-binding kinetics of $n A C h R s$ in exposed DF. We propose that some of the pathobiologic effects of tobacco products on extracellular matrix turnover stem from Nic-induced alterations in the physiologic control of the unfolding of the genetically determined program of growth and of the tissue remodeling function of DF; these effects may be mediated, in part, by Nic-induced alterations in the structure and function of fibroblast nAChR channels.

\section{Results}

\section{The nAChR-Dependent Regulation of the Cell Cycle Progression of Human DF}

To elucidate the biologic functions of nAChRs expressed in DF, we measured the nicotinergic effects on transcription and translation of the genes encoding the cell cycle and apoptosis regulators by RT-PCR and WB, respectively. We used the gene-specific RT-PCR primers and Abs listed in Tables 1 and 2, respectively. The RT-PCR designed to amplify the human cell cycle regulator genes, p21, p53, Ki-67, cyclin D1 and PCNA, and the apoptosis regulator genes, $\mathrm{BCl}-2$ and caspase 3 , all yielded products of expected sizes. As seen in Figure 1A, DF stimulated with the nicotinic agonist Nic $(10 \mu \mathrm{M})$ for 24 hours showed increased levels of the p21 (1.9-fold), cyclin D1 (1.9-fold), PCNA (2.1-fold), Ki-67 (28-fold), caspase 3 (2-fold) (all $p<0.05)$, and Bcl-2 (1.7-fold; $p>0.05$ ) mRNA transcripts. These effects of Nic were mostly blocked in the presence of $50 \mu \mathrm{M}$ of the nicotinic antagonist mecamylamine (Mec) (Fig. 1A), indicating that the observed alterations in the cell cycle and apoptosis gene expression resulted from the intracellular events initiated because of Nic binding to nAChRs expressed by DF. Glyceraldehyde-3-phosphate dehydrogenase gene amplification remained constant in each experiment. Negative control experiments failed to produce any amplified product (data not shown).

Changes in the gene expression of each of the cell cycle and apoptosis markers detectable by WB were consistent with those determined by RT-PCR. We found that the relative protein amounts of $\mathrm{p} 21$, cyclin D1, PCNA, Ki-67, Bcl-2, and caspase 3 increased after 24-hour exposure to Nic (Fig. 1B). The relative amounts 
Table 1. Human Genes Studied by RT-PCR

\begin{tabular}{|c|c|c|c|c|}
\hline Name & Abbreviation & Gene name & Accession no. & Primers \\
\hline $\begin{array}{l}\text { Glyceraldehyde-3 phosphate } \\
\text { dehydrogenase }\end{array}$ & GAPDH & GAPDH & J04038 & $214-234,401-449$ \\
\hline \multicolumn{5}{|l|}{ nAChR subunits } \\
\hline$\alpha 3$ & $\alpha 3$ & CHRNA3 & M37981 & $375-394,840-863$ \\
\hline$\alpha 5$ & $\alpha 5$ & CHRNA5 & M83712 & $433-456,868-892$ \\
\hline$\alpha 7$ & $\alpha 7$ & CHRNA7 & U40583 & $367-388,814-835$ \\
\hline$\beta 2$ & $\beta 2$ & CHRNB2 & U62437 & $1302-1326,1747-1770$ \\
\hline$\beta 4$ & $\beta 4$ & CHRNB4 & U48861 & $1271-1296,1561-1584$ \\
\hline \multicolumn{5}{|l|}{ Cell cycle regulators } \\
\hline Proliferation-related Ki-67 antigen & Ki-67 & MKI67 & $X 65550$ & $299-321,727-750$ \\
\hline Proliferation cell nuclear antigen & PCNA & PCNA & AF527838 & $236-259,535-555$ \\
\hline Cyclin D1 & Cyl1 & CCND1 & M64349 & $279-301,568-589$ \\
\hline p53-dependent G2 arrest & p53 & REPRIMO & AB043585 & $475-496,820-839$ \\
\hline Cdk inhibitor p21 binding protein 1 & p21 & TOK-1 & AB040450 & $319-340,601-623$ \\
\hline \multicolumn{5}{|l|}{ Apoptosis markers } \\
\hline Bcl-2, apoptosis inhibitor & Bcl2 & $B C L 2$ & NM_138578 & $853-875,1346-1223$ \\
\hline $\begin{array}{l}\text { Caspase- } 3 \text {, apoptosis-related } \\
\text { cysteine proteinase }\end{array}$ & CPP32 & CASP3 & U13737 & $397-418,850-870$ \\
\hline \multicolumn{5}{|l|}{ Extracellular matrix components } \\
\hline Collagen type $\mid \alpha 1$ & COL1A1 & COL1A1 & NM_000088 & $376-399,730-751$ \\
\hline Elastin & ELN & $E L N$ & NM_000501 & $827-848,1214-1235$ \\
\hline Matrix metalloproteinase 1 & MMP-1 & MMP1 & NM_002421 & $518-539,996-1017$ \\
\hline
\end{tabular}

Table 2. The Primary Abs Used in this Study

\begin{tabular}{|c|c|c|c|c|c|}
\hline $\mathrm{Ab}$ & Isotype & Host & $\begin{array}{c}\text { Concentration } \\
(\mu \mathrm{g} / \mathrm{ml})\end{array}$ & Epitope & Reactivity \\
\hline$\alpha 3 \mathrm{nAChR}^{a}$ & $\lg G$ & Rabbit & 1 & CPLMAREDA & Human and rodents \\
\hline$\alpha 5 \mathrm{nAChR}^{a}$ & $\lg G$ & Same & 1 & CPVHIGNANK & Same \\
\hline$\alpha 7 \mathrm{nAChR}^{a}$ & $\lg G$ & Same & 1 & CFVEAVSKDFA & Same \\
\hline$\beta 2 \mathrm{nAChR}^{a}$ & $\lg G$ & Same & 1 & HSDDHSAPSSK & Same \\
\hline$\beta 4 \mathrm{nAChR}^{a}$ & $\lg G$ & Same & 1 & EGPYAAORD & Same \\
\hline $\mathrm{p} 21^{b}$ & lgG1 & Same & 1 & TSMTDFYHSKRR & Same \\
\hline $\mathrm{p} 53^{b}$ & $\lg G 1$ & Same & 5 & RHSVV & Same \\
\hline Cyclin $\mathrm{D} 1^{b}$ & $\lg G 2$ & Same & 1 & 1-295 (whole protein) & Same \\
\hline PCNA $^{b}$ & $\lg \mathrm{g} 2$ & Same & 2.5 & 1-261 (whole protein) & Same \\
\hline $\mathrm{BCl}-2^{b}$ & $\lg G$ & Same & 0.5 & $20-30$ a.a. & Same \\
\hline Caspase $3^{b}$ & $\lg G$ & Same & 5 & Whole protein & Same \\
\hline $\mathrm{Bax}^{b}$ & $\lg G$ & Same & 5 & Same & Same \\
\hline Collagen $1^{b}$ & $\lg G$ & Same & 5 & Same & Same \\
\hline MMP-1 $1^{b}$ & $\lg G$ & Same & 1 & Same & Same \\
\hline Elastin $^{c}$ & $\lg G$ & Same & 5 & Same & Same \\
\hline B-actin ${ }^{c}$ & $\lg \mathrm{G} 1$ & Mouse & 0.2 & PPIAALVIPSGSGL & Same \\
\hline Fibroblast surface protein $(1 \mathrm{~B} 10)^{c}$ & $\lg G$ & Mouse & 2.5 & Whole protein & Same \\
\hline $\mathrm{Ki}-67^{d}$ & $\lg \mathrm{G} 1$ & Same & 1 & $2597-2896$ & Same \\
\hline
\end{tabular}

${ }^{a}$ Research and Diagnostic Antibodies, Benicia, California.

${ }^{b}$ Oncogene Research Products, Boston, Massachusetts.

${ }^{c}$ Sigma Chemical Co., St. Louis, Missouri.

${ }^{a}$ Santa Cruz Biotechnology.

of each cell cycle and apoptosis protein increased in a range from 1.8- to 2.5-fold, and Mec attenuated these effects of Nic (Fig. 1B). Each protein band was visualized at the expected molecular weight: cyclin D1 at approximately $35 \mathrm{kDa}$ (Bartek et al, 1993), PCNA at $37 \mathrm{kDa}$ (Waseem and Lane, 1990), Ki-67 at 345 kDa (Gerdes,
1990), Bcl-2 at $24 \mathrm{kDa}$ (Tomicic and Kaina, 2001), caspase 3 at $32 \mathrm{kDa}$ (Mooney and Miller, 2001), and p21 at $21 \mathrm{kDa}$. The mRNA and protein levels of p53 in experimental and control DF did not differ significantly (not shown). Thus, the results of the WB assay supported the findings of the RT-PCR experiments. 


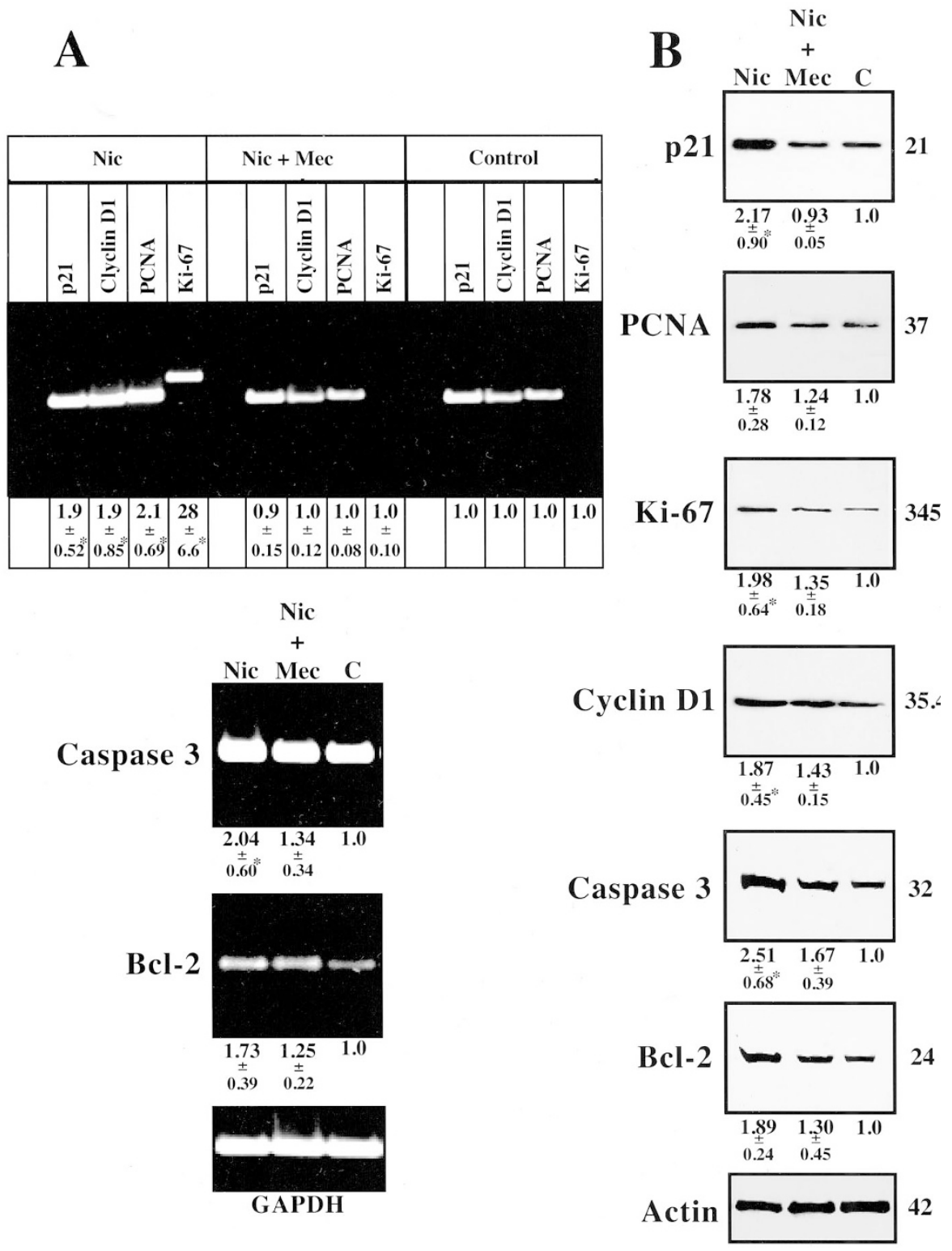

\section{Figure 1.}

Gene expression changes of the cell cycle and apoptosis markers in human dermal fibroblasts (DF) exposed to nicotine (Nic). Total RNA and proteins were isolated from human DF treated for 24 hours with $10 \mu \mathrm{m}$ Nic in the absence or presence of $50 \mu \mathrm{m}$ mecamylamine (Mec). The relative amounts of mRNA transcripts and protein levels of the cell cycle markers were measured and the results expressed as described in "Materials and Methods." Asterisks indicate significant $(p<0.05)$ differences from control. A, The mRNA levels of the cell cycle genes p21, cyclin D1, PCNA, and Ki-67 and the cell apoptosis markers Bcl-2 and caspase 3 determined by RT-PCR using specific primers (Table 1) and cDNA from exposed versus nonexposed (Control) DF. A PCR product of the expected size was amplified by each primer set specific for p21 (305 bp), cyclin D1 (311 bp), PCNA (320 bp), Ki-67 (452 bp), Bcl-2 (493 bp), and caspase-3 (473 bp). The levels of mRNAs coding for p21, cyclin D1, PCNA, Ki-67, Bcl-2, and caspase 3 were increased in the exposed, compared with control, DF. Amplification of the glyceraldehyde-3-phosphate dehydrogenase (GAPDH) gene product was used to normalize the cDNA content in each sample and as a positive control for RT-PCR effectiveness. The ratio data are the means \pm SD of the values obtained in at least three independent experiments. The images represent typical appearance of the bands in gels. B, The cell cycle proteins p21, cyclin D1, PCNA, and Ki-67 and the antiapoptotic protein Bcl-2 and the proapoptotic enzyme caspase 3 visualized in Western blots. The molecular weight of each protein is shown in $\mathrm{kDa}$ to the right of the gels. In Nic-treated cultures, the relative amounts of the studied cell cycle proteins increased in the range from 1.8- to 2.5-fold, and Mec abolished most of these changes. The ratio data are the means \pm SD of the values obtained in at least three independent experiments. The images represent typical appearance of the bands in gels. Staining of the protein bands was absent in the negative control experiments in which the membranes were treated without primary $\mathrm{Ab}$ or with irrelevant primary $\mathrm{Ab}$ of the same isotype and host (not shown).

\section{Elucidation of the Role of $\alpha 3$ nAChR in Mediating Nicotinergic Control of Fibroblast Cell Cycle Progression Using KO Mice}

In pilot studies we screened total human fibroblast RNA with primers specific for various nAChR subunits and amplified sequences of the classic subunits that can comprise neuronal-type nAChR channels (Hall et al, 2000). Because Nic effects on cultured DF could be abolished by Mec, which is an efficient blocker of the $\alpha 3$-containing neuronal (ie, "ganglionic")-type heteromeric nAChRs (Grando et al, 1995), including the "brain type" receptors, we sought to elucidate the role 
of the channels comprised with the contribution of the $\alpha 3$ subunit (ie, $\alpha 3 \beta 2(\beta 4) \pm \alpha 5$ ) in the nicotinergic control of DF. To dissect the role of $\alpha 3$-containing nAChRs, we used both quantitative RT-PCR and WB to measure alterations in the expression of genes coding for the cell cycle and apoptosis markers in DF from neonates delivered by $\alpha 3+/-$ mice, followed by genotyping (Fig. 2A). Gene-specific primers for the murine cell cycle and apoptosis markers p21, p53, cyclin D1, Ki-67, PCNA, Bcl-2, Bax, and caspase 3 (Table 3) amplified products of the expected sizes (Fig. 2B). Compared with wild-type DF, the $\alpha 3$ KO DF showed decreased mRNA levels of p21 and PCNA (both $p<0.05$ ) and cyclin $\mathrm{D} 1, \mathrm{Ki}-67$, and $\mathrm{Bcl}-2(p>0.05)$ and significantly $(p<0.05)$ increased mRNA levels of p53, Bax, and caspase 3 . The glyceraldehyde-3-phosphate dehydrogenase (GAPDH) gene amplification remained constant in each experiment (Fig. 2B).

Changes in gene expression detected by WB were similar to those determined by RT-PCR. We found decreased protein levels of the cell cycle markers p21 (2.7-fold) and PCNA (4.2-fold) (both $p<0.05$ ) and Ki-67 (1.2-fold; $p>0.05)$ and the antiapoptotic Bcl-2 (1.2-fold; $p>0.05)$. We also found increased levels of p53 (2.3-fold) and both proapoptotic Bax (2.8-fold) and caspase 3 (1.8-fold) (all $p<0.05)$. The protein level of cyclin D1 remained practically unchanged (Fig. $2 \mathrm{C})$. Thus, changes in the cell cycle progression of murine DF lacking $\alpha 3$ were found to be opposite to those observed in human DF treated with Nic, suggesting that fibroblast $\alpha 3$-containing $\mathrm{nAChRs}$ mediated, at least in part, the effects of Nic on fibroblast growth and differentiation.

\section{Functional Inactivation of $\alpha 3$ nAChR by AsOs Abolishes Nic-Induced Changes in the Cell Cycle Progression in Human DF}

To further elucidate the role of fibroblast $\alpha 3 \mathrm{nAChR}$ in mediating pathobiologic effects of Nic on the cell cycle progression of DF, we asked whether functional inactivation of $\alpha 3 \mathrm{nAChR}$ with receptor-selective AsOs could prevent Nic-dependent changes in the expression of cell cycle markers in these cells. Phosphorothioated and FITC-tagged AsOs targeted to mRNA for the $\alpha 3$ nAChR subunit (Table 4) were used to functionally inactivate ACh signaling through this receptor-mediated pathway in cultured human foreskin DF. Nuclear AsOs uptake of the FITC-tagged AsOs by DF was monitored using a fluorescence microscope (Fig. 3A). The treatment protocol was optimized to allow maximal inhibition (>90\%), as judged from the results of quantitative receptor protein analysis by WB (Fig. 3B). The specificity of $A b$ binding to the immunoblotting membranes was confirmed by (i) the appearance of the $\alpha 3$ protein band at the expected molecular weight (Nguyen et al, 2000) and (ii) the absence of this band in negative control experiments omitting primary $\mathrm{Ab}$ or replacing it with an irrelevant, species- and isotype-matched $\mathrm{Ab}$ (not shown).

To determine the effect of inhibited $\alpha 3 \mathrm{nAChR}$ expression on the fibroblast cell cycle progression, monolayers of DF were incubated with fibroblast growth medium-2 (FGM) in the presence (experiment) or absence (baseline) of a mixture of three phosphorothioated anti- $\alpha 3$ AsOs or the same concentration of sense oligonucleotide used as a negative control for AsOs (Table 4). As seen in Figure 3C, functional deletion of $\alpha 3 \mathrm{nAChR}$ resulted in characteristic changes in cell cycle gene expression, which were similar to those observed in DF from $\alpha 3 \mathrm{KO}$ mice (Fig. $2 \mathrm{C})$. This effect of anti- $\alpha 3$ AsOs markedly differed from that of the control (sense) oligonucleotide, which produced only minor fluctuations of the protein levels of the cell cycle regulators under consideration (Fig. 3C). Untreated, control DF or DF transfected with the sense oligonucleotide responded to treatment with $\mathrm{Nic}$ in similar way to that observed in the experiments with normal human DF reported in Figure 1. In marked contrast, DF transfected with anti- $\alpha 3$ AsOs failed to respond to Nic with up-regulated expression of the cell cycle markers (Fig. 3C), indicating that the $\alpha 3$ $\mathrm{nAChR}$-coupled pathway of ACh signaling mediated, at least in part, the nicotinergic effects on fibroblast cell cycle progression.

\section{Nicotinergic Control of the Tissue Remodeling Activity of DF}

We next asked whether Nic alters the reported (Carty et al, 1996; Tipton and Dabbous, 1995; Tomek et al, 1994) ability of DF to produce extracellular matrix proteins via the $\mathrm{nAChR}$-mediated pathway. To answer this question, we used two independent experimental approaches: (1) measuring the effects of Nic on the gene expression of collagen type $\mid \alpha 1$ and elastin in cultured normal human DF; and (2) characterizing the levels of expression of these genes in $\alpha 3 \mathrm{KO}$ DF. We also measured the nicotinergic effects on fibroblast MMP-1 expression because of previous reports that smoking is associated with up-regulated expression of tissue-remodeling enzymes (Lahmann et al, 2001a; Morimoto et al, 1997). RT-PCR analysis of RNA extracted from human DF preincubated with $10 \mu \mathrm{M}$ Nic for 24 hours revealed increased expression of collagen $\mid \alpha 1$ and elastin at both the transcriptional level (1.4- and 8.2-fold, respectively; Fig. 4A) and the translational level (1.9- and 2.1-fold, respectively; Fig. 4B) levels. Both the mRNA and the protein levels of MMP-1 also increased (1.3- and 1.9-fold, respectively; Fig. 4, A and B). To further elucidate the role of $\alpha 3$ $\mathrm{nAChR}$ in mediating nicotinergic control of the tissue remodeling function of DF, we performed quantitative analysis of collagen $\mid \alpha 1$, elastin, and MMP- 1 in DF grown from $\alpha 3 \mathrm{KO}$ versus wild-type mice using RTPCR and WB. The $\alpha 3-/-$ DF showed a 1.3-fold decrease of both the mRNA (Fig. $4 \mathrm{C}$ ) and the protein (Fig. 4D) levels of elastin, compared with $\alpha 3+/+$ DF. The mRNA level of collagen $\mid \alpha 1$ was not altered in $\alpha 3-/-$ DF (Fig. 4C). Surprisingly, the mRNA and protein levels of MMP-1 and the protein level of collagen $\mid \alpha 1$ were increased in $\alpha 3-/-$ DF (Fig. 4, C and D). Thus, Nic might alter elastin production through the signaling pathways downstream from $\alpha 3$ $\mathrm{nAChR}$, whereas changes in collagen $\mid \alpha 1$ and MMP-1 

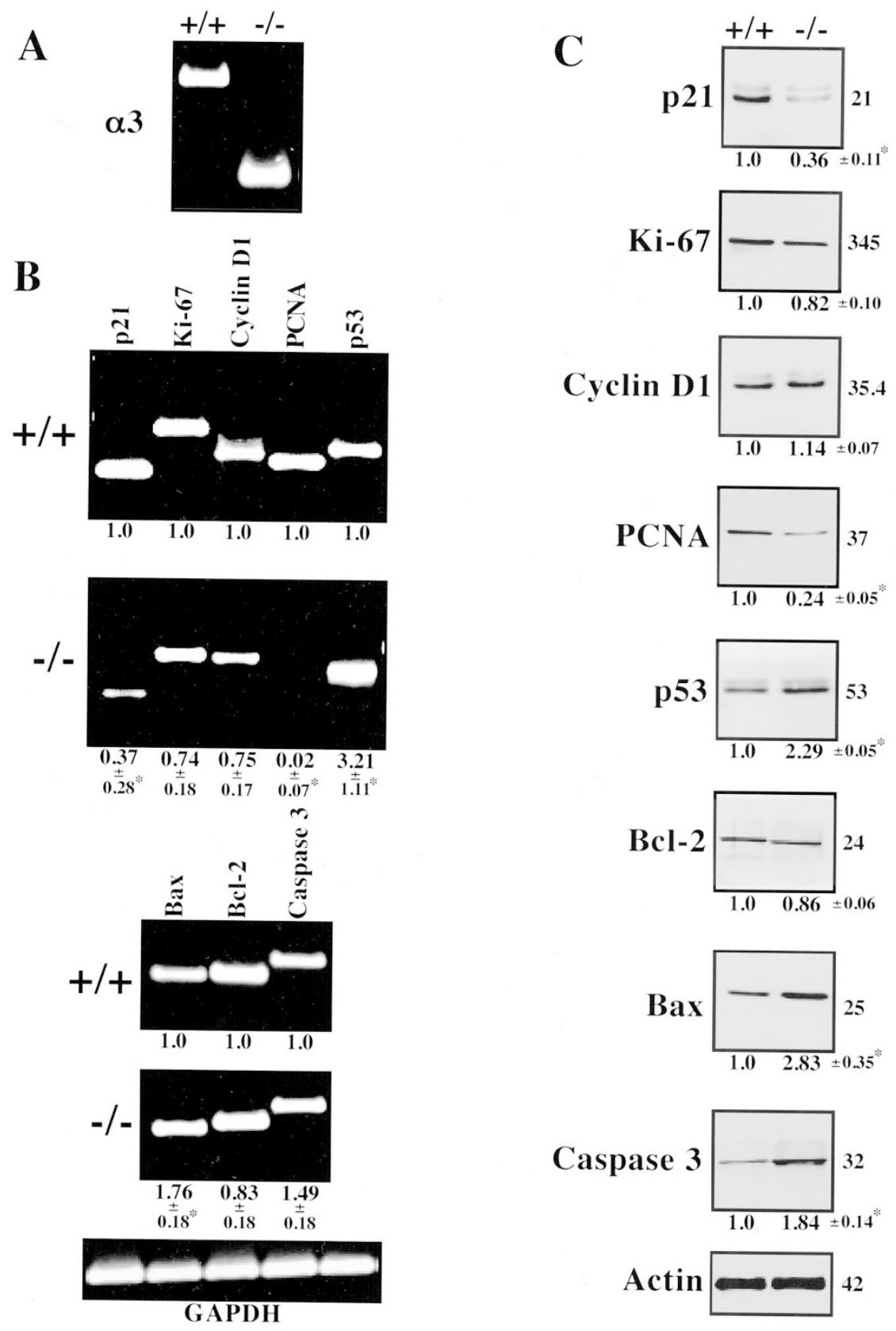

Figure 2.

Alterations in the cell cycle and apoptosis gene expression in $\alpha 3$ KO DF. A, PCR-based genotyping of $\alpha 3+/+$ and $\alpha 3-/-$ mice. Genomic DNA extracted from neonatal mice was used in the RT-PCR assay, as detailed in "Materials and Methods," with the following primers: 5'-GTGGATCCCTCCGGCCATCTTTAAGAG-3' (wild-type forward), 5'-GACTGTGATGACAATGGACAAGGTGAC-3' (wild-type reverse), and 5'-TGGCGCGAAGGGACCACCAAAGAACGG-3' (mutant reverse). After 30 cycles, the PCR analysis identified the $\alpha 3$ homozygous null $(-/-)$, heterozygous $(+/-)$, and wild-type $(+/+)$ phenotypes. The gel shows representative PCR profiles of homozygous mice from a progeny of a heterozygous $\alpha 3+/-$ mouse. The homozygous null $(-/-)$ mouse showed a single lower band, the wild-type $(+/+)$ showed a single upper band, whereas the heterozygous $(+/-)$ showed both the upper and the lower band (not shown). B, Analysis of the expression of cell cycle and apoptosis genes in $\alpha 3$ KO DF by RT-PCR. Total RNA was isolated from the second passage, $\sim 75 \%$ confluent monolayers of DF grown from neonatal $\alpha 3$ homozygous null $(-/-)$ and wild-type $(+/+)$ mice and used in the RT-PCR assays described in "Materials and Methods." Each primer set listed in Table 3 yielded a PCR product of the expected size: 233 bp for p21, 499 bp for Ki-67, 482 bp for cyclin D1, 307 bp for PCNA, 389 bp for p53, 470 bp for Bax, 474 bp for Bcl-2, and 494 bp for caspase 3. A gene expression ratio of 1 was given to the wild-type $(+/+)$ animals. The $\alpha 3$ null mutation was associated with decreased transcription of the genes coding for p21, cyclin D1, Ki-67, PCNA, and Bcl-2 in a range from 1.4- to 50-fold and increased transcription of the genes encoding p53 (3.2-fold), Bax (1.8-fold), and caspase $3(1.5$-fold). The ratio data are the means \pm SD of the values obtained in at least three independent experiments. The images represent typical appearance of the bands in gels. The negative control experiments did not yield any PCR products (not shown). Asterisks indicate significant $(p<0.05)$ differences from control. C, Analysis of the expression of cell cycle and apoptosis genes in $\alpha 3$ KO DF by WB. Total protein was isolated from the same cells as in B and used in the WB assay described in "Materials and Methods," with the Abs listed in Table 2. The molecular weight of each protein is shown in kDa to the right of the gels. Changes in the gene expression of each of the cell cycle and apoptosis markers detectable by WB were consistent with those determined by RT-PCR. In $\alpha 3-/-$ DF, the relative amounts of p21 decreased 2.7-fold, Ki-67 1.2-fold, PCNA 4.2-fold, and Bcl-2 1.2-fold; the relative amounts of p53, Bax, and caspase 3 increased 2.3-, 2.8-, and 1.8-fold, respectively; and the relative amount of cyclin D1 did not change compared with $\alpha 3+/+$ DF. The staining of these proteins was absent in the negative control experiments described in the legend to Figure 1B. Asterisks indicate significant $(p<0.05)$ differences from control. 
Table 3. Murine Genes Studied by RT-PCR

\begin{tabular}{|c|c|c|c|c|}
\hline Name & Abbreviation & Gene name & Accession no. & Primers \\
\hline $\begin{array}{l}\text { Glyceraldehyde-3 phosphate } \\
\text { dehydrogenase }\end{array}$ & GAPDH & Gapd & M17701 & $214-234,401-449$ \\
\hline \multicolumn{5}{|l|}{ nAChR subunits } \\
\hline$\alpha 3$ & $\alpha 3$ & Chrna3 & X03440 & $434-455,895-918$ \\
\hline$\alpha 5$ & $\alpha 5$ & Chrna5 & AF204689 & $788-801,1238-1257$ \\
\hline$\alpha 7$ & $\alpha 7$ & Chrna7 & AF225980 & $555-575,1027-1048$ \\
\hline$\beta 2$ & $\beta 2$ & Chrnb2 & AF299083 & $278-298,678-710$ \\
\hline$\beta 4$ & $\beta 4$ & Chrnb4 & NM052806 & $455-473,923-944$ \\
\hline \multicolumn{5}{|l|}{ Cell cycle regulators } \\
\hline Proliferation-related Ki-67 antigen & Ki-67 & $M k i-67$ & X82786 & $1091-1113,1570-1589$ \\
\hline Proliferation cell nuclear antigen & PCNA & Pcna & X57800 & $131-150,437-415$ \\
\hline Cyclin D1 & Cyl 1 & Ccnd & M64403 & $339-369,797-820$ \\
\hline p53-dependent G2 arrest & p53 & Reprimo & AB043586 & $94-118,463-482$ \\
\hline Cdk inhibitor p21 binding protein 1 & p21 & Cdkn1a & AB017817 & $131-154,341-363$ \\
\hline \multicolumn{5}{|l|}{ Apoptosis markers } \\
\hline Bcl-2, apoptosis inhibitor & $\mathrm{Bcl} 2$ & $B c / 2$ & L31532 & $376-399,730-751$ \\
\hline Bax, Bcl-2 associated $\mathrm{X}$ protein & $\operatorname{Bax}$ & Bax & AB029557 & $326-349,755-778$ \\
\hline $\begin{array}{l}\text { Caspase } 3 \text {, apoptosis related cysteine } \\
\text { protease }\end{array}$ & СРP32 & Casp3 & NM_009810 & $225-246,657-676$ \\
\hline \multicolumn{5}{|l|}{ Extracellular matrix components } \\
\hline Collagen type $\mid \alpha 1$ & Col1 & Col1a1 & K01688 & $\begin{array}{l}4821-4840 \\
5250-5270\end{array}$ \\
\hline Elastin & Ela & Eln & XM_109452 & $458-477,791-814$ \\
\hline Matrix metalloproteinase 1 & MMP-1 & Mmp1 & NM_032006 & $300-324,768-792$ \\
\hline
\end{tabular}

Table 4. Oligodeoxynucleotides (ODN) Used in this Study

\begin{tabular}{|c|c|c|}
\hline ODN & Sequence & Function \\
\hline$\alpha 3.1$ & $\mathbf{5}^{\prime}-\left(\mathbf{F}^{a}\right) \mathbf{C C A C C T G G A A A T C C C C A A C A - 3 ^ { \prime }}$ & fluorescein ODN $\alpha 3$ antisense \\
\hline$\alpha 3.2$ & $\mathbf{5}^{\prime}$ - $\mathbf{C}^{b}$ AAATAGACGGTGCTCAGCCT ${ }^{b} \mathbf{C}-3^{\prime}$ & phosphorothioated $\alpha 3$ antisense \\
\hline$\alpha 3.3$ & $\mathbf{5}^{\prime}-\mathbf{C}^{b} \mathrm{TCAAATAGACGGTGCTCAGC}^{b} \mathrm{C}-3^{\prime}$ & phosphorothioated $\alpha 3$ antisense \\
\hline$\alpha 3.4$ & 5'-C ${ }^{b}$ CTGACGGTGTTTCTCCTGGTGA ${ }^{b} \mathrm{~T}^{-3} 3^{\prime}$ & phosphorothioated $\alpha 3$ antisense \\
\hline$\alpha 3.5$ & $\mathbf{5}^{\prime}-\mathbf{C}^{b} \mathrm{TGCGGTGTAAGGTGTGATTG}^{b} \mathbf{C}-3^{\prime}$ & phosphorothioated $\alpha 3$ sense \\
\hline
\end{tabular}

${ }^{a}$ Fluorescein.

${ }^{b}$ Phosphorothioate.

gene expression could be mediated by other type(s) of nAChRs expressed in DF.

\section{Nic Alters nAChR Expression in Human DF}

Because preincubation of human bronchial epithelial cells and oral keratinocytes with $\mathrm{Nic}$ had altered expression of $\mathrm{nAChRs}$ in these cells (Arredondo et al, 2001; Zia et al, 1997, 2000), we hypothesized that exposure to Nic may also alter the function and/or structure of $\mathrm{nAChRs}$ expressed in DF. To elucidate the effects of Nic exposure on nicotinergic signaling in DF, we first measured the number and ligand-binding affinity of nAChRs in Nic-exposed versus nonexposed cells, using whole cell radioligand-binding assays with the nicotinic radioligand $\left[{ }^{3} \mathrm{H}\right]$ epibatidine $\left(\left[{ }^{3} \mathrm{H}\right] \mathrm{Ep}\right)$. The saturable binding of $\left[{ }^{3} \mathrm{H}\right] \mathrm{Ep}$ was achieved at $4^{\circ} \mathrm{C}$ (Fig. $5 \mathrm{~A})$, demonstrating a population of high-affinity binding sites with a $K d$ of $82.6 \mathrm{pm}$ and a maximal binding capacity $\left(\mathrm{B}_{\max }\right)$ of $24.3 \mathrm{fmol} / \mathrm{mg}$ protein or approximately $4.6 \times 10^{3} \mathrm{nAChRs}$ per single cell (Table 5).
Preincubation of DF with $10 \mu \mathrm{M}$ Nic for 24 hours dramatically changed the $\left[{ }^{3} \mathrm{H}\right] \mathrm{Ep}$ binding parameters (Table 5). The $B_{\text {max }}$, characterizing total number of nAChR binding sites, increased by more than 2-fold and became equal to $69.8 \mathrm{fmol} / \mathrm{mg}$ protein, whereas the $K d$ value, characterizing receptor ligand-binding affinity, increased to $135 \mathrm{pm}$. These changes could be partially blocked when the DF were preincubated with $\mathrm{Nic}$ in the presence of $50 \mu \mathrm{M} \mathrm{Mec}$, indicating that alterations of the pharmacologic parameters of $\left[{ }^{3} \mathrm{H}\right] \mathrm{Ep}$ binding to DF resulted from their overstimulation with Nic through their nAChRs.

We next investigated the effects of $\mathrm{Nic}$ on the structural composition of the nAChR channels expressed on the cell membrane of human DF, by measuring the expression of the genes coding for different $\mathrm{nAChR}$ subunits in DF preincubated with 10 $\mu \mathrm{M}$ Nic given alone or in combination with $50 \mu \mathrm{M} \mathrm{Mec.}$ Gene-specific primers for human $\alpha 3, \alpha 5, \alpha 7, \beta 2$, and $\beta 4$ subunits (Table 1) amplified products of the expected sizes (Fig. 5B). Nic exposure increased the 


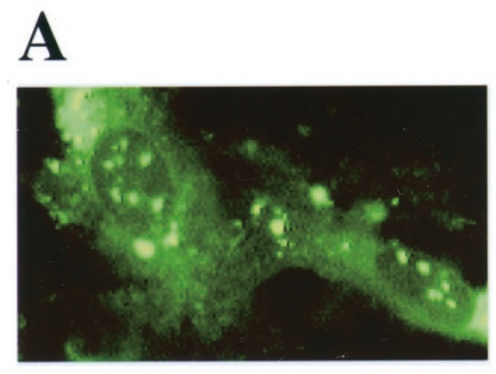

B

$\alpha 3$

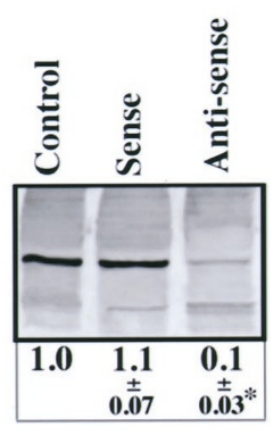

60

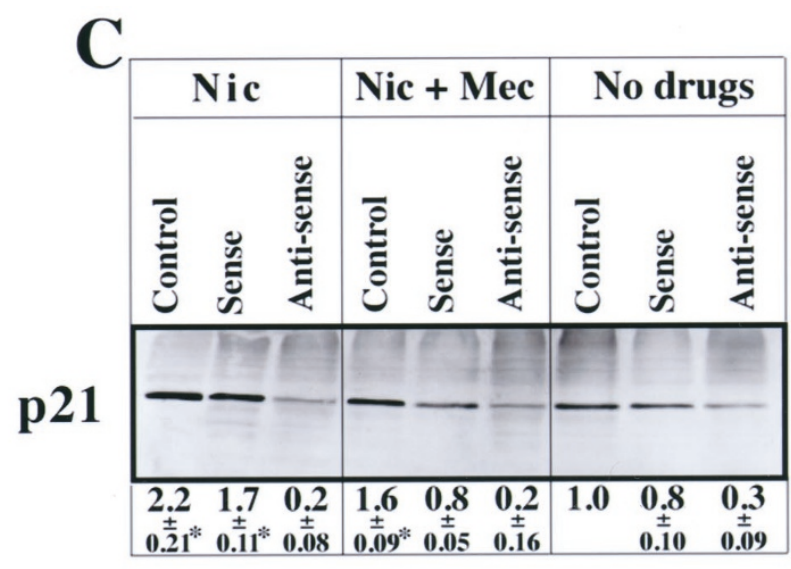

21

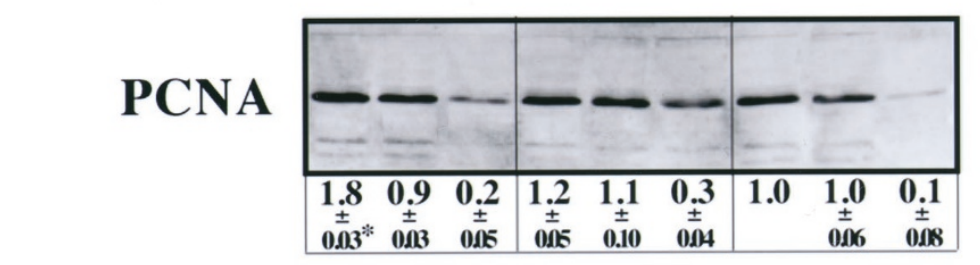

37

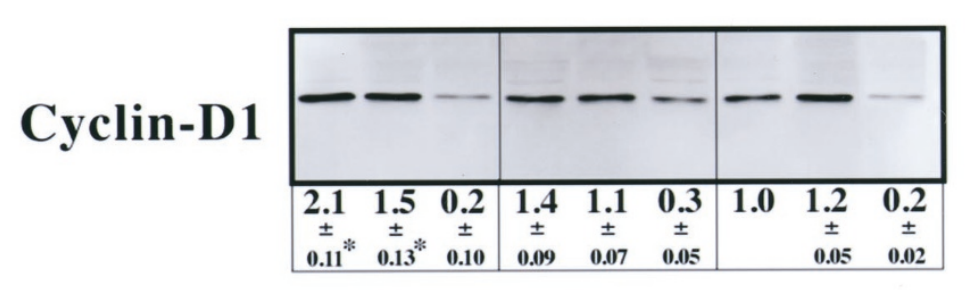

35.4

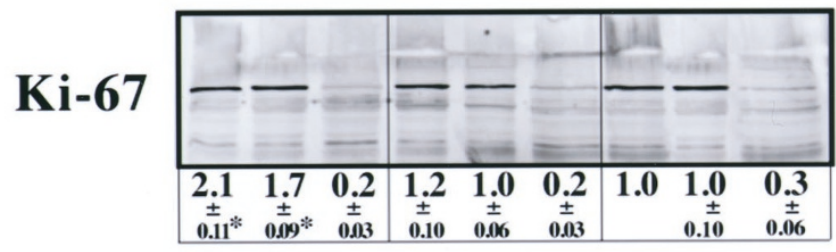

345

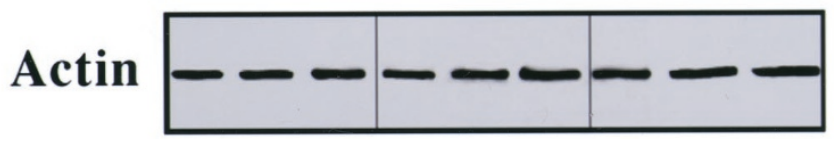

42

Figure 3.

Transfection of human DF with anti- $\alpha 3$ antisense oligonucleotides (As0s) abolishes Nic-induced changes in cell cycle markers. A, Intracellular accumulation of FITC-labeled $\alpha 3$ AsOs. FITC-labeled AsOs (0.5 $\mu \mathrm{m}$; Table 4) was added to second passage human foreskin DF. Localized FITC-labeled As0s was viewed live via phase-contrast fluorescence microscopy after a 24-hour incubation; magnification $\times 400$. Note: anti- $\alpha 3 \mathrm{AsOs}$ is distributed into the nucleus as well as the cytoplasm. Control oligonucleotide was similarly distributed (not shown). B, Effect of anti- $\alpha 3 \mathrm{AsOs}$ on the $\alpha 3$ nicotinic acetylcholine receptor (nAChR) subunit protein in human DF. The cells were seeded in 24-well plates at a density of $5 \times 10^{4} /$ well and incubated in a $5 \% \mathrm{CO}_{2}$ incubator for 72 hours in fibroblast growth medium (FGM) in the presence of LipofectAMINE PLUS alone (control), $20 \mathrm{~nm}$ sense oligonucleotide, or $20 \mathrm{~nm}$ each of three phosphorothioated As0s (Table 4). The monolayers were washed, the cells were scraped, and the cellular proteins were analyzed by WB as detailed in "Materials and Methods." In each lane, $20 \mu \mathrm{g}$ of total protein was subjected to electrophoresis, blotted, and probed with a rabbit anti- $\alpha 3 \mathrm{Ab}$ characterized previously (Nguyen et al, 2000). The $\alpha 3$ band appeared at the expected molecular weight of $60 \mathrm{kDa}$. The anti- $\alpha 3 \mathrm{As} 0 \mathrm{~s}$ dramatically reduced the intensity of the $60-\mathrm{kDa}$ receptor band. Densitometric analysis showed at least $90 \%$ reduction of $\alpha 3$, compared with control. Control (ie, sense) oligonucleotide only moderately altered the amount of $\alpha 3$ protein. The ratio data are the means \pm SD of the values obtained in at least three independent experiments. The images represent typical appearance of the bands in gels. The staining of the receptor bands was absent in the negative control experiments in which the membranes were treated without primary Ab, with irrelevant primary Ab of the same isotype and host, or the antipeptide 
mRNA levels of all subunits in a range from 1.8- to 3.8-fold. These effects of Nic were partly blocked in the presence of $50 \mu \mathrm{M} \mathrm{Mec}$, indicating that regulation of the $n A C h R$ subunit gene expression in DF is coupled to the nAChR-mediated intracellular signaling pathway. Treatment with Nic also up-regulated synthesis of the nAChR subunit proteins, as judged from the results of WB experiments that used rabbit antinAChR subunit polyclonal Abs previously characterized by us (Arredondo et al, 2001). The relative ratios of protein expression increased for all nAChR subunits under investigation, and $\mathrm{Mec}$ attenuated the effects of Nic (Fig. 5C). Notably, the level of up-regulation of $\alpha 3$ and $\alpha 5$ at the translational level (2.1- and 2.3-fold, respectively) did not reach the level of up-regulation observed at the transcriptional level. Furthermore, the rate of up-regulated expression of $\alpha 5$ protein exceeded that of $\alpha 3$ (Fig. 5B). Therefore, although the expression of both these subunits was increased in exposed DF, the actual number of $\alpha 5$-containing $\alpha 3$ nAChR channels [ie, $\alpha 3 \beta 2(\beta 4) \alpha 5]$ among different $\mathrm{nAChR}$ types might be higher than that in nonexposed DF.

To verify that all $\mathrm{nAChRs}$ subunits found to be expressed in cultured DF by the RT-PCR and WB assays are expressed in these cells residing in the dermis and grown in culture, we used the indirect immunofluorescence (IF) assay to visualize $\alpha 3, \alpha 5, \alpha 7$, $\beta 2$, and $\beta 4 \mathrm{nAChR}$ subunits in cryostat sections of normal human skin and in monolayers of human DF, respectively. In addition to specific staining of the cell membrane of nonpermeabilized DF in culture, Abs against each of the above subunits specifically stained spindle cells in the papillary and reticular parts of the dermis (Fig. 6, green pseudocolor). We established that the dermal spindle cells that carried nAChRs were indeed DF by double-staining experiments in which, in addition to the rabbit anti-nAChR subunit $A b$, the skin specimens were also stained with the murine antifibroblast Ab 1B10 (Fig. 6, red pseudocolor). All 1B10positive cells were found to be also nAChR positive. No fluorescence staining could be detected in skin specimens incubated without primary $A b$ or when a receptor antiserum was preincubated with the peptide used for immunization (not shown).

\section{Discussion}

In this study, we demonstrate for the first time that Nic can directly affect normal growth and the tissue remodeling function of DF via signaling pathways down- stream from $n A C h R s$ expressed on the plasma membranes of these cells. DF are the primary cell type responsible for the maintenance of dermal homeostasis, regulating a balance between the synthesis and degradation of extracellular matrix proteins and the ground substance (Odland, 1991). The dermal matrix is composed mainly of collagen and elastin synthesized primarily by DF. The major dermal component is type I collagen. Elastin is a minor component of the dermis; however, it serves an important function providing the elasticity of the skin. Dermal tissue remodeling, either physiologic or pathologic, is a highly organized process that involves the selective action of MMPs that degrade major components of the extracellular matrix (Kahari and Saarialho-Kere, 1997). Alterations in the composition, organization, and structure of the collagenous extracellular matrix in the dermis play important roles in both precocious skin aging and impaired wound healing (Ashcroft et al, 1997a; Kletsas et al, 2000; Reiser et al, 1995; Takeda et al, 1992). For instance, both skin aging and chronic wound healing are associated with the up-regulation of fibroblast MMPs, leading to atrophy of extracellular matrix architecture (Ashcroft et al, 1997b; West, 1994). Several studies have indicated the association between tobacco smoking, on the one hand, and skin aging and aberrant wound healing, on the other, but the exact mechanism of tobacco smoke-induced cutaneous changes is currently unknown (Aizen and Gilhar, 2001; Ernster et al, 1995; Frances, 1998; Frick and Seals, 1994; Kadunce et al, 1991; Kwiatkowski et al, 1996; Silverstein, 1992). We hypothesized that the pathobiologic effects of tobacco products stem, at least in part, from overstimulation of the nicotinergic signaling pathways in DF.

Our findings of profound and plethoric effects of Nic on the cell cycle gene expression in DF help explain previously reported changes in fibroblast viability, growth, and development induced by tobacco products. In this study, we investigated functional coupling of fibroblast nAChRs to regulation of cell development and function by measuring Nic effects on expression of the genes encoding specific cell cycle progression and apoptosis markers as well as the genes encoding stromal proteins and an enzyme mediating breakdown of the collagenous stromal tissue. A 24-hour exposure to Nic up-regulated expression of p21, cyclin D1, PCNA, Ki-67, Bcl-2, and caspase 3. The observed nicotinergic effects on DF were elicited at the concentration of Nic that is physiologically relevant because it

Figure 3. (cont'd)

antisera before treatment of the blotting membrane was preincubated with the $\alpha 3$ peptide used for immunization (not shown). Asterisk indicates significant $(p<0.05)$ differences from control. C, Changes in the expression of cell cycle markers in AsOs-transfected DF treated with Nic. Relative amounts of p21, PCNA, cyclin-D1, and Ki-67 were analyzed by WB of the total protein isolated from human DF transfected with anti- $\alpha 3$ AsOs or with sense oligonucleotide or from nontransfected DF (Control) after 24-hour incubation in FGM containing no drugs or $10 \mu \mathrm{M}$ Nic with or without $50 \mu \mathrm{M}$ Mec. The cell cycle marker protein contents were measured by standard densitometry of the specific bands in the gels, as described in "Materials and Methods." The gene expression ratio of 1 was given to the drug-untreated, control DF. The ratio data are the means \pm SD of the values obtained in at least three independent experiments. The images represent typical appearance of the bands in gels. A dramatic decrease of the relative amounts of individual cell cycle markers was found in the drug-untreated DF transfected with anti- $\alpha 3 \mathrm{AsO}$ s. The transfection with anti- $\alpha 3$ AsOs also abolished Nic-induced changes in the cell cycle markers, which could be observed in the intact DF and DF transfected with sense oligonucleotide. In the latter cultures, Mec abolished Nic effects. The staining of the protein bands was absent in the negative control experiments in which the membranes were treated without primary Ab or with irrelevant primary Ab of the same isotype and host (not shown). Asterisks indicate significant $(p<0.05)$ differences from control. 

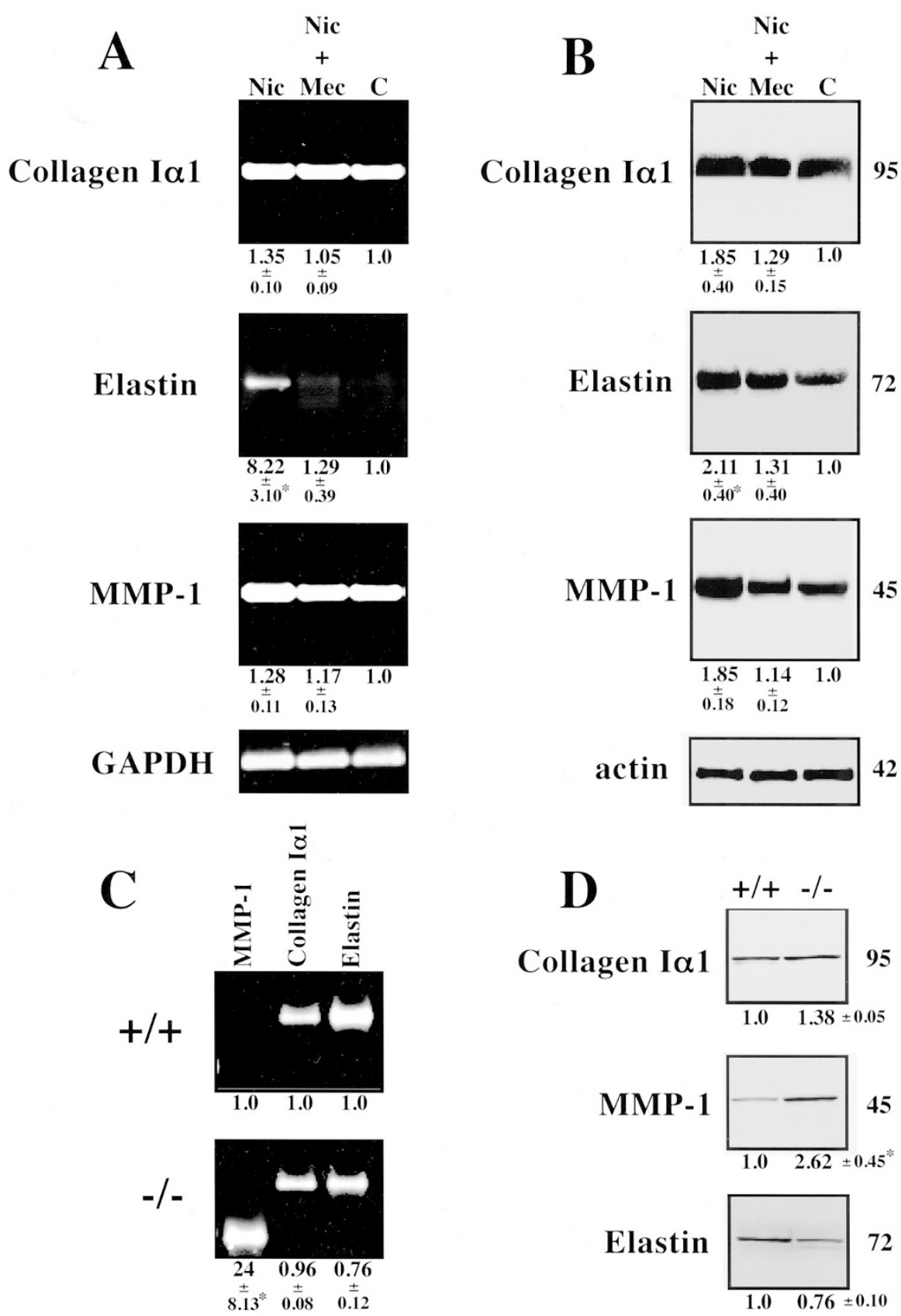

Figure 4.

Nicotinergic effects on the tissue remodeling function of DF. The mRNA and protein contents in the experimental and control DF were measured by standard densitometry of the specific bands in the gels, as described in "Materials and Methods." Asterisks indicate significant $(p<0.05)$ differences from control. A, RT-PCR analysis of RNA extracted from human DF preincubated with $10 \mu \mathrm{m}$ Nic for 24 hours in the presence of absence of $50 \mu \mathrm{m}$ Mec versus untreated control DF (C). The relative gene expression levels were determined using gene-specific RT-PCR primers (Table 1). Amplification yielded PCR products of the expected sizes: 675 bp for collagen I $\alpha 1,468 \mathrm{bp}$ for elastin, and $499 \mathrm{bp}$ for matrix metalloprotease-1 (MMP-1). Amplification of the GAPDH gene product (354 bp) was used to normalize the cDNA content in each sample and as a positive control for RT-PCR effectiveness. Preincubation of DF with Nic increased the transcription of the studied genes in a range from 1.3- to 8.2-fold, and Mec abolished these changes. B. The fibroblast matrix proteins visualized in Western blots at the expected molecular weights (shown in $\mathrm{kDa}$ to the right of the gels) of the $15 \%$ SDS-PAGE-resolved fibroblast proteins using specific Abs (Table 2). Total protein was isolated from the same cells as in A. Changes in the Nic-induced gene expression detected by WB were similar to those determined by RT-PCR. In the presence of Mec, the Nic effects on the protein levels of collagen $\mid \alpha 1$, elastin, and MMP-1 were attenuated. Staining of these proteins was absent in the negative control experiments described in the legend to Figure 1B. C, RT-PCR analysis of the extracellular matrix protein mRNAs in DF from $\alpha 3 \mathrm{KO}$ neonatal mice. Each primer set (Table 3) yielded PCR product of the expected size: 651 bp for collagen I $\alpha 1,657$ bp for elastin, and 493 bp for MMP-1. The level of elastin mRNA was decreased 1.3-fold and that of MMP-1 was increased 24 -fold in $\alpha 3-/-$ DF, compared with $\alpha 3+/+$ DF, whereas that of collagen I $\alpha 1$ changed only moderately. D, WB analysis of extracellular matrix proteins in DF from $\alpha 3 \mathrm{KO}$ neonatal mice. Total protein was isolated from the same cells as in $\mathrm{C}$ and used in the WB assay with the Abs listed in Table 2. A gene expression ratio of 1 was given to the protein levels determined in DF from the wild-type $(+/+)$ animals. Lack of $\alpha 3 \mathrm{nAChR}$ was associated with a 1.3-fold decrease of elastin production and 2.6and 1.4-fold increases of MMP-1 and collagen $\mid \alpha 1$ protein levels, respectively. The staining of these proteins was absent in the negative control experiments described in the legend to Figure $1 \mathrm{~B}$. 


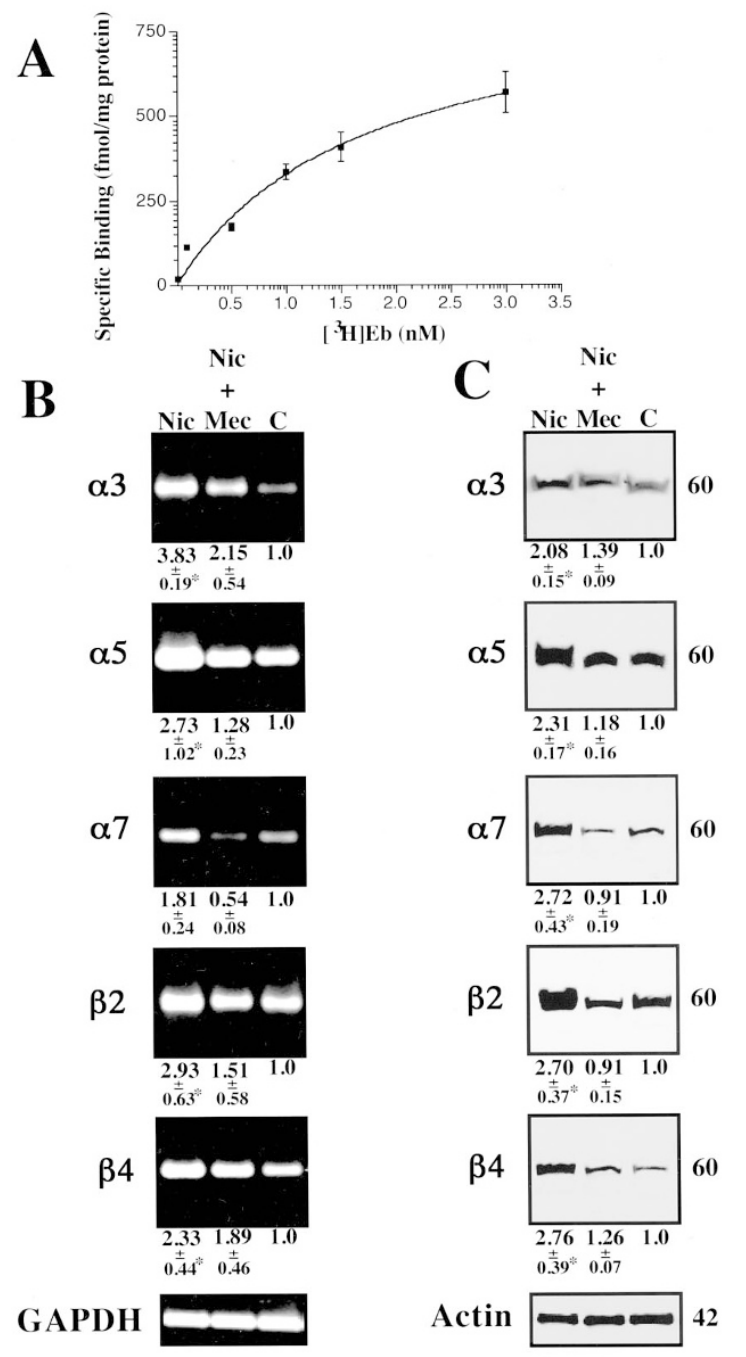

Figure 5.

Effects of Nic exposure on the ligand-binding function and subunit composition of fibroblast nAChRs. A, Specific binding of $\left[{ }^{3} \mathrm{H}\right]$ epibatidine $\left(\left[{ }^{3} \mathrm{H}\right] \mathrm{Ep}\right)$ to cultured human DF. The saturable binding was achieved in the monolayers of DF grown in the flat-bottomed 24-well plates as described in "Materials and Methods." Each point represents a mean specific binding calculated in triplicate samples of $2 \times 10^{5} \mathrm{DF} /$ well exposed to increasing concentrations of $\left.{ }^{3} \mathrm{H}\right] \mathrm{Ep}$ for 4 hours at $4^{\circ} \mathrm{C}$ in the absence (total binding) or presence (nonspecific binding) of $300 \mu \mathrm{m}$ nonlabeled Nic. The specific binding was obtained by subtracting the nonspecific binding from the total binding. $B$ and $C$, Alterations of the nAChR subunit gene expression in human DF pre-exposed to Nic. Second passage normal human DF were treated with $10 \mu \mathrm{m}$ Nic in the absence or presence of $50 \mu \mathrm{m}$ Mec for 24 hours, after which the total RNA and proteins were extracted and used in MRNA and protein assays as described in "Materials and Methods." The ratio data are the means \pm SD of the values obtained in at least three independent experiments. The images represent typical appearance of the bands in gels. B, The relative nAChR subunit gene expression levels determined using subunit-specific RT-PCR primers (Table 1). Amplification yielded PCR products of the expected sizes: 489 bp for $\alpha 3$, $460 \mathrm{bp}$ for $\alpha 5,469 \mathrm{bp}$ for $\alpha 7,468 \mathrm{bp}$ for $\beta 2$, and $474 \mathrm{bp}$ for $\beta 4$. Preincubation with Nic increased the transcription of these nAChR subunits genes. The relative amount of each up-regulated $\mathrm{nAChR}$ subunit increased in a range from 1.8- to 3.8-fold. The presence of Mec abolished these changes. C, The nAChR subunit proteins visualized in Western blots at the expected molecular weights (shown in $\mathrm{kDa}$ to the right of the gels) in the 15\% SDS-PAGE-resolved fibroblast proteins using subunit-specific Abs (Table 2). An increase of the relative amount of individual $\mathrm{nAChR}$ subunits in response to preincubation with Nic ranged from 2.1- to 2.8-fold. In the presence of Mec, Nic-induced changes were attenuated. Staining of these proteins was absent in the negative control experiments described in the legend to Figure 1B. Asterisks indicate significant $(p<0.05)$ differences from control. approaches the levels found in smokers and snuffers. On smoking days, Nic concentrations in human plasma range between 4 and $72 \mathrm{ng} / \mathrm{ml}$ (approximately $0.1 \mu \mathrm{m}$; Hill et al, 1983; Peacock et al, 1993) and are extremely high in saliva $>1300 \mathrm{ng} / \mathrm{ml}$ (Lindell et al, 1993; Russell et al, 1980) (ie, in the micromolar range). The peak Nic plasma levels in the snuffers are similar to the peak values in heavy smokers (Russell et al, 1980, 1981). Because we (reviewed in Grando, 2001) and others (Heeschen et al, 2001; Joad et al, 1993, 1995; Kwon et al, 1999; Theilig et al, 1994) have reported previously that in in vitro and in vivo experiments the maximal effects of Nic on non-neuronal cells occur at the dose range of $10^{-8}$ to $10^{-6} \mathrm{M}$, we exposed DF to $10 \mu \mathrm{M}$ Nic. Since the effects of Nic on DF could be abolished by $\mathrm{Mec}$, an antagonist of the neuronal (ganglionic) type of $\mathrm{nAChRs}$ that are comprised with participation of the $\alpha 3$ subunit (Grando et al, 1995), we further hypothesized that fibroblast $\alpha 3$ nAChR might be chiefly involved. This hypothesis was tested in experiments with DF from $\alpha 3 \mathrm{KO}$ mouse. We expected to find that functional deletion of the $\alpha 3$ signaling pathway in murine DF would produce effects on the expression of the genes coding for cell cycle progression and apoptosis markers under consideration that would be reciprocal to those elicited by exposure of human DF to Nic. As expected, $\alpha 3$ deletion was associated with a decrease of p21, cyclin D1, PCNA, Ki-67, and Bcl-2. $\alpha 3-/-$ DF also featured up-regulated expression of caspase 3 , Bax, and p53. To ultimately determine the role of $\alpha 3$-containing $\mathrm{nAChR}$ channels in mediating effects of Nic on the cell cycle progression of DF, we repeated Nic exposure experiments using human DF transfected with anti- $\alpha 3$ AsOs. As expected, the changes in the cell cycle gene expression in transfected DF were in the most part similar to those seen in DF from $\alpha 3$ mice. Transfection with AsOs, but not with control (sense) oligonucleotide, practically eliminated the responsiveness of DF to Nic-dependent changes in the cell cycle. We did not perform similar Nic exposure experiments in cultures of DF derived from $\alpha 3 \mathrm{KO}$ mice for the following two reasons. First, in contrast to acute inhibition of $\alpha 3$ expression with anti-receptor AsOs, deletional mutation of $\alpha 3$ in a KO mouse resulted in a compensatory overexpression of other types of fibroblast $\mathrm{nAChRs}$ (Fig. 5). Second, there seem to be some fundamental differences between human and murine DF, such as lack of measurable level of Ki-67 mRNA in human DF (Fig. 1A), in contrast to its abundant presence in murine DF (Fig. 2B).

Table 5. $\left[{ }^{3} \mathrm{H}\right]$ Ep Binding Parameters in Human DF Incubated with Nic

\begin{tabular}{lccc}
\hline & & \multicolumn{2}{c}{$B_{\max }$} \\
\cline { 3 - 4 } Treatment & $K d(\mathrm{nM})$ & $(\mathrm{fmol} / \mathrm{mg}$ protein) & (binding sites/cell) \\
\hline Nic & 0.135 & 69.75 & 13,210 \\
Nic + Mec & 0.091 & 26.31 & 5,130 \\
Control & 0.083 & 24.25 & 4,593 \\
\hline
\end{tabular}




\section{Fibroblast culture}

Dermis
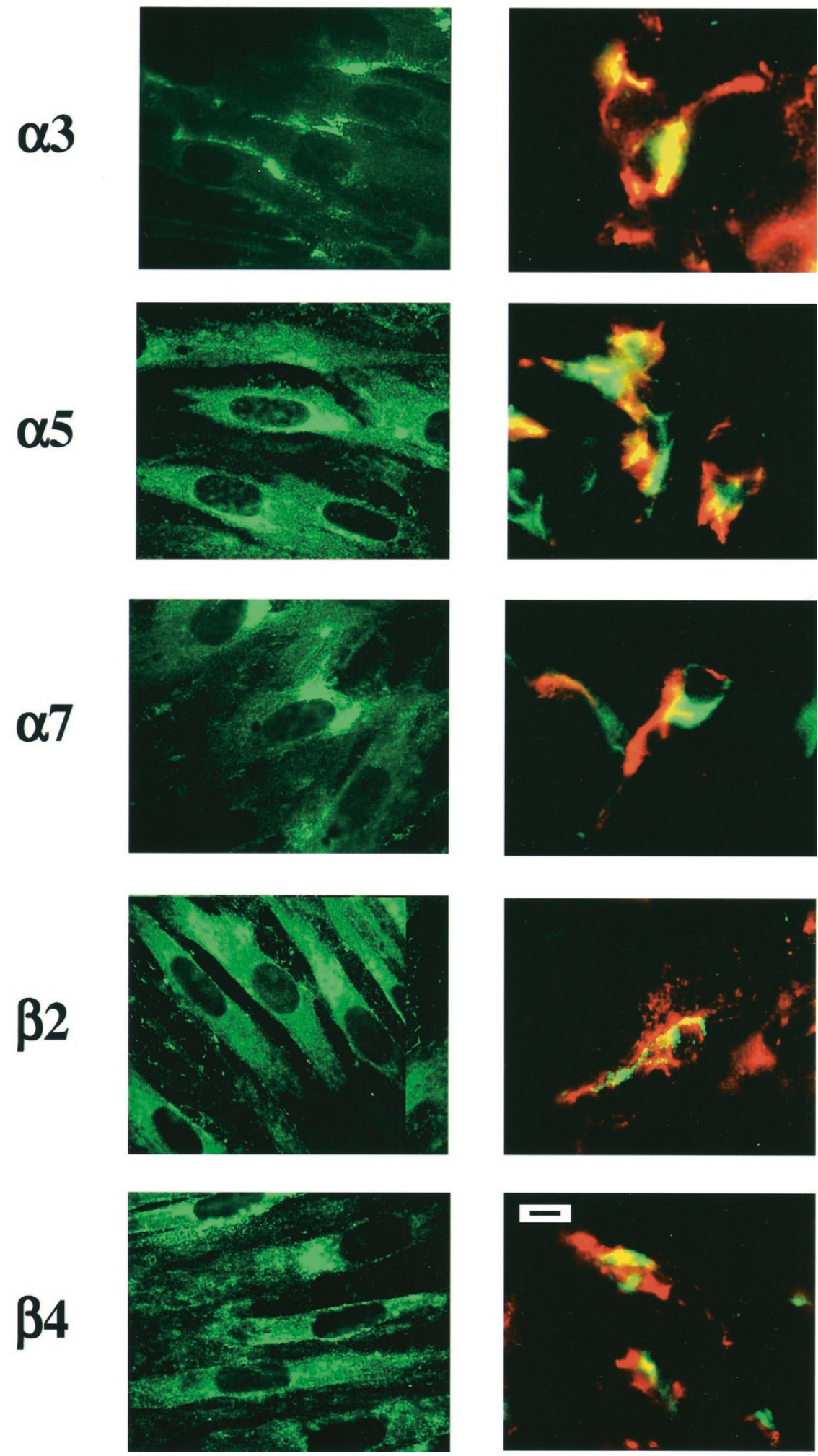

Figure 6.

Visualization of fibroblast nAChRs in human skin specimens. Rabbit polyclonal Abs raised against unique protein sequences of $\alpha 3, \alpha 5, \alpha 7, \beta 2$, and $\beta 4$ nAChR subunits were used to probe fibroblast monolayers in 6-well plates and cryostat sections of freshly frozen specimens of normal human foreskins by indirect immunofluorescence (IF). The DF were identified by the fibroblast-specific Ab $1 B 10$ in double-staining experiments. Binding of anti-nAChR Abs was visualized with FITC-labeled anti-rabbit IgG Ab (green pseudocolor), and binding of the $1 \mathrm{~B} 10 \mathrm{Ab}$ was visualized by tetramethylrhodamine isothiocyanate-labeled anti-mouse IgG Ab (red pseudocolor). Omission of the primary Ab abolished IF staining (not shown). Scale bar $=5 \mu \mathrm{m}$. 
The overall effects of Nic on the expression of the cell cycle progression markers in DF were stimulatory. However, because the gene expression of the proapoptotic protease caspase 3 was also increased, compensatory mechanisms might be activated as well. The stimulatory effects of Nic were apparently mediated by $\alpha 3 \mathrm{nAChR}$, because lack of this receptormediated signaling pathway in $\alpha 3 \mathrm{KO}$ mice was associated with changes in the expression of cell cycle and apoptosis markers consistent with the growth inhibition effect. Thus, the endogenous cytotransmitter ACh may sustain fibroblast viability because of its ionotropic action mediated by constant activation of $\alpha 3$ containing nAChRs. The crucial role of ion channels, such as $n A C h R s$, in the maintenance of cell viability has been previously demonstrated by others (Mulle et al, 1992). There is a solid body of evidence that tobacco smoke and/or pure Nic can directly affect fibroblasts residing in the mucocutaneous and pulmonary tissues. The reported nicotinergic effects on these cells include both growth-stimulatory (Peacock et al, 1993) and growth-inhibitory actions (Aizen and Gilhar, 2001; Checchi et al, 1999; Giannopoulou et al, 1999; Ishii et al, 2001; James et al, 1999; Konno et al, 1991; Lahmouzi et al, 2000; Nakamura et al, 1995). The presumable controversy of the reported results may be easily explained by differences in the duration of the exposures and concentrations of Nic used and by the presence of other biologically active substances in tobacco smoke. Diverse nicotinergic effects on cell growth and differentiation were also observed in other types of tissue cells, such as endothelial cells (Heeschen et al, 2001) and keratinocytes (Arredondo et al, 2001; Grando et al, 1996; Kwon et al, 1999). Similar to DF, epidermal and oral keratinocytes and endothelial cells all express the $\alpha 3$-type nAChR channels that may also contain $\alpha 5, \beta 2$, and $\beta 4$ subunits (Grando et al, 1995; Macklin et al, 1998; Nguyen et al, 2000). Under pathologic conditions, such as chronic tobacco usage, aberrant signaling through $\alpha 3$-containing $\mathrm{nAChRs}$ was shown to play a role in atherosclerotic plaque development and tumor growth (Heeschen et al, 2001). Thus, the molecular mechanism of the pathobiologic effects of Nic on different types of integumental cells may involve the newly discovered functional coupling of nAChRs to the regulation of gene expression in non-neuronal cells (Zhang et al, 2001a, 2001b). Indeed, some of the differences in cell function markers observed in our experiments using DF from different species might actually reflect $\mathrm{mRNA}$ and/or protein stability rather then changes in the transcription and/or translation of the genes in question.

The nicotinergic effects on the tissue remodeling function of human DF characterized in the present study include the up-regulation of both stromal proteins, collagen type $\mathrm{I} \alpha 1$ and elastin, and of the extracellular matrix degrading enzyme MMP-1. We observed from to 1.3- to 8.2-fold increase of expression of the genes coding for these molecules at the transcriptional and translational levels in human DF incubated with Nic for 24 hours, which could be abolished by Mec. These nAChR-mediated effects of Nic may, in part, account for alterations in the stromal homeostasis produced by tobacco products and pure Nic. Significantly more MMP-1 mRNA has been found in the skin of smokers than of nonsmokers, suggesting that smoking-induced MMP-1 might be important in the skin-ageing effects of tobacco smoking (Lahmann et al, 2001a). In vitro exposure experiments have demonstrated that tobacco extract increases collagen production by fibroblasts (Chamson et al, 1982) and that Nic significantly increases degradation of type I collagen (Tipton and Dabbous, 1995). Nic has been shown to directly up-regulate the expression of several matrix MMPs that are critical in wound healing, such as collagenase-1, stromelysin-1, and gelatinase A (Carty et al, 1996). In contrast, upon treatment of human DF with tobacco smoke extract, the mRNA expression of tissue inhibitors of MMPs, TIMP-1 and TIMP-3, remained unchanged (Yin et al, 2000). On the other hand, smoking has been shown to downregulate collagen synthesis in skin, which was interpreted as a possible etiologic factor for accelerated skin aging (Raitio et al, 1999, 2000). In another study, treatment of cardiac fibroblasts with Nic led to a $31 \%$ decrease in the abundance of mRNA for pro $\alpha 1$ (I) but not pro $\alpha 2(I)$ collagen, compared with control untreated cells, and decreased collagenase activity (Tomek et al, 1994). Again, the differences in the nicotinergic effects reported by different research groups may be explained by different experimental conditions and fibroblast tissue types used. Cumulative results, however, convincingly demonstrate that the nicotinergic regulation of the fibroblast tissue remodeling function involves $\mathrm{nAChR}$-mediated effects on the expression of structural components and proteolytic enzymes of the extracellular matrix.

We sought to determine a role for the $\alpha 3 \mathrm{nAChR}$ signaling pathway in mediating nicotinergic effects on the tissue remodeling function of DF. In experiments with $\alpha 3-/-$ DF, we found that both the mRNA and protein levels of elastin, but not collagen type I $\alpha 1$ or MMP-1, were decreased. On the other hand, production of MMP-1 was increased. These results suggest that although the expression of elastin is up-regulated through the $\alpha 3 \mathrm{nAChR}$ pathway, the Nic-induced up-regulation of collagen type I $\alpha 1$ and MMP-1 expression in DF could be mediated by activation of other type(s) of nAChRs operating in these cells.

It has been demonstrated in the past that overstimulation with Nic can lead to both accumulation of collagens types I and III and overexpression of $\alpha 7$ $\mathrm{nAChR}$ in the airway stroma (Sekhon et al, 1999, 2002). Therefore, we hypothesized that in addition to the pure pharmacologic effects on fibroblast growth and function characterized above, the downstream signaling from fibroblast $\mathrm{nAChRs}$ might also mediate Nic-induced alterations of the repertoire of $n A C h R$ subunits expressed by the exposed DF. We knew that Nic-induced alterations in the structure and function of the cellular cholinergic system, caused by its chronic pharmacologic stimulation, can occur in the neural system (Flores et al, 1992; James and Nordberg, 
1995; Miao et al, 1998) and in nonneuronal cells, such as bronchial epithelial cells and oral and epidermal keratinocytes (Arredondo et al, 2001; Zia et al, 1997, 2000). The results showed that in DF, too, overexposure to Nic alters both the ligand-binding kinetics and the subunit composition of $\mathrm{nAChRs}$. Changes in $\alpha 3$, $\alpha 5, \alpha 7, \beta 2$, and $\beta 4 \mathrm{nAChR}$ subunit gene expression were found at both the mRNA and protein levels. Through RT-PCR and WB, we detected from 1.7- to 2.4-fold increase. These changes in the repertoire of fibroblast $\mathrm{nAChRs}$ may interfere with the nicotinergic control of DF by ACh.

The cutaneous cytotransmitter ACh is released locally by non-neuronal cells and can regulate tissue homeostasis in an autocrine and paracrine fashion by exhibiting a plethora of biologic effects on different cell types inhabiting skin (reviewed in Grando, 1997). The highest concentration of free $\mathrm{ACh}$ is found in human skin (ie, $1000 \mathrm{pmol}$ ACh/gm), compared with airways (33 pmol), oral mucosa (8 pmol), intestine (800 pmol), and gall bladder (12 pmol) (Klapproth et al, 1997). ACh, Nic, and cholinergic compounds elicit biologic effects on DF through binding to two different classes of cholinergic receptors, the nicotinic and the muscarinic types of ACh receptors. In addition to nAChRs characterized in this study, DF also express $\mathrm{m} 2, \mathrm{~m} 4$, and $\mathrm{m} 5$ muscarinic ACh receptor subtypes that are coupled to the regulation of $\mathrm{Ca}^{2+}$ metabolism in these cells (Buchli et al, 1999). In addition to DF, the two classes of ACh receptors coexist on the cell membranes of several types of non-neuronal cells and are functionally interrelated (Bering et al, 1987; Evinger et al, 1994; Falugi et al, 1993; Richman and Arnason, 1979; Stewart and Forrester, 1978; Young and Laing, 1991). Acting via its nicotinic and muscarinic receptors, ACh has been shown to inhibit apoptosis and to exhibit growth factor-like effects (Carty et al, 1996; Lindenboim et al, 1995; Maneckjee and Minna, 1994; Pinkas-Kramarski et al, 1992; Yan et al, 1995). Thus, physiologic control of DF by ACh can be mediated by two distinct types of biochemical events: (1) the ionic events, generated by opening of ACh-gated ion channels represented by fibroblast nAChRs; and (2) the metabolic events, elicited by ACh binding to the $G$ protein coupled single-subunit transmembrane glycoproteins, or muscarinic ACh receptors. This diversity may be required to subserve a plethora of biologic effects of ACh on DF. Nic, too, may use these signaling pathways to produce its pathobiologic effect on dermal tissue remodeling. The Nic-induced alterations may stem from genomic and nongenomic effects resulting from overstimulation of the nicotinergic pathways of physiologic control of DF by ACh. This novel pathophysiologic mechanism may include Nicinduced changes in the repertoire of $\mathrm{ACh}$ receptors expressed by DF. For instance, results of this study indicate that chronic stimulation of DF with Nic leads to relative increase of the proportion of $\alpha 5$-containing $\alpha 3 \mathrm{nAChR}$ channels on the fibroblast cell membrane. A switch in the $\mathrm{nAChR}$ subunit composition from predominantly $\alpha 3 \beta 2$ and/or $\alpha 3 \beta 4$ channels to $\alpha 3 \beta 2 \alpha 5$ and $\alpha 3 \beta 4 \alpha 5$ channels can alter $\mathrm{Ca}^{2+}$ metabolism in these cells (Gerzanich et al, 1998), leading to reciprocal changes in cell cycle progression and function.

In conclusion, the aberrant gene expression of both nAChRs and the cell cycle and tissue remodeling regulators observed in DF exposed to Nic strongly suggest that certain pathobiologic effects of tobacco products on the connective tissue are mediated by Nic-induced alterations in the nicotinergic control of fibroblast growth and function by the endogenous cytotransmitter ACh. The results obtained in this study provide scientific basis for new approaches to clinical solutions to ameliorate the medical consequences of tobacco use and intercede in disease pathways.

\section{Materials and Methods}

\section{In Vitro Nic Exposure Experiments}

Normal human DF were obtained from neonatal foreskins (this study has been approved by the University of California Davis Human Subjects Review Committee). Murine DF were obtained from the skin of 2- to 4-day-old $\alpha 3 \mathrm{KO}$ ( $\alpha 3$ null) mice prepared by deletion of exon 5 in the $\alpha 3$ gene, as described previously (Xu et al, 1999). All control mice were $\alpha 3+/+$ littermates of $\alpha 3-/-$ neonates from a progeny of a heterozygous $\alpha 3+/-$ mouse. The genotype of pups used in experiments was established as detailed elsewhere (Xu et al, 1999) by an experimenter who was blind to the results of experiments involving DF from these mice. All of the procedures were approved by the institutional animal care use committee in accordance with federal guidelines. Skin tissue samples destined for primary cell culture were freed of clotted blood and rinsed in $\mathrm{Ca}^{2+}$ - and $\mathrm{Mg}^{2+}$-free PBS (Gibco BRL, Gaithersburg, Maryland). Samples were then cut into 3- to 4-mm pieces, placed dermis up into a sterile cell culture dish containing $2.5 \mathrm{ml}$ of $0.125 \%$ trypsin (Sigma Chemical Company, St. Louis, Missouri) and $2.5 \mathrm{ml}$ of minimum essential medium (Gibco BRL) supplemented with $50 \mu \mathrm{g} / \mathrm{ml}$ gentamicin, $50 \mu \mathrm{g} / \mathrm{ml}$ kanamycin sulfate, $10 \mathrm{U} / \mathrm{ml}$ penicillin $\mathrm{G}, 10 \mu \mathrm{g} / \mathrm{ml}$ streptomycin, and $5 \mu \mathrm{g} / \mathrm{ml}$ amphotericin (all from Gibco BRL). Tissue was incubated overnight at $37^{\circ} \mathrm{C}$ in a humidified atmosphere with $5 \% \mathrm{CO}_{2}$. The dermal sheets were then separated from the lamina propria in minimum essential medium containing 20\% heatinactivated newborn calf serum (Gibco BRL), and individual DF were isolated by gentle pipetting followed by centrifugation. The DF were grown in $25-\mathrm{cm}^{2}$ or $75-\mathrm{cm}^{2}$ Falcon culture flasks (Corning Glass Works, Corning, New York) in special FGM supplemented with $1 \mathrm{ng} / \mathrm{ml}$ human fibroblast growth factor, $5 \mu \mathrm{g} / \mathrm{ml}$ insulin, $2 \%$ fetal bovine serum, and $50 \mu \mathrm{g} / \mathrm{ml}$ each of gentamicin and amphotericin B (all from Clonetics, San Diego, California) in a $5 \% \mathrm{CO}_{2}$ environment at $37^{\circ} \mathrm{C}$, as detailed elsewhere (Buchli et al, 1999). Cell culture medium was changed every 3 days, and cultures were passaged at approximately $80 \%$ confluence. After three to five passages, DF were used in experiments. In Nic exposure experiments, the monolayers of human DF were exposed for 24 hours to 10 
$\mu \mathrm{M}$ pure Nic dissolved in FGM in the absence or presence of $50 \mu \mathrm{M} \mathrm{Mec}$, the specific nicotinic antagonist (both from Sigma Chemical Company), for 24 hours at $37^{\circ} \mathrm{C}$ and $5 \% \mathrm{CO}_{2}$. Control DF were incubated in FGM without any additions. The experiments were performed in triplicates for both exposed and control, nonexposed cultures, and the cells from each culture were harvested and used in experiments separately. In each individual culture, $2.5 \times 10^{6}$ viable DF were used to extract total RNA and proteins.

\section{RT-PCR Assay}

Total RNA was extracted from cultured human and murine DF using the guanidinium thiocyanate-phenolchloroform extraction procedure (TRIzol Reagent, Gibco BRL), as described elsewhere (Chomczynski and Sacchi, 1987). The quantity and structural integrity of RNA samples was confirmed by electrophoresis on $1.1 \%$ agarose/2.2 $\mathrm{M}$ formaldehyde gels and by optical density of the $260 / 280 \mathrm{~nm}$ ratio. Only samples that showed intact $28 \mathrm{~S}$ and $18 \mathrm{~S}$ ribosomal RNA bands and exhibited a $260 / 280 \mathrm{~nm}$ ratio $>1.8$ were used in the experiments. One microgram of dried, DNasetreated RNA was reverse transcribed in $20 \mu \mathrm{l}$ of RT-PCR mix (50 mm Tris [pH 8.3], $6 \mathrm{~mm} \mathrm{MgCl}_{2}, 40 \mathrm{~mm}$ $\mathrm{KCl}, 25 \mathrm{~mm}$ dNTPs, $1 \mu \mathrm{g}$ Oligo-dt [Gibco BRL], $1 \mathrm{~mm}$ dithiothreitol, $1 \mathrm{U}$ of RNase inhibitor [Boehringer Mannheim, Mannheim, Germany], and $10 \mathrm{U}$ of SuperScript II [Gibco, BRL]) at $42^{\circ} \mathrm{C}$ for 2 hours. The PCR was performed in a final volume of $50 \mu$ l containing 2 $\mu$ l of the single-strand cDNA product, $10 \mathrm{~mm}$ Tris- $\mathrm{HCl}$ (pH 9.0), $5 \mathrm{~mm} \mathrm{KCl,} 5 \mathrm{~mm} \mathrm{MgCl}_{2}, 0.2 \mathrm{~mm}$ dATP, $0.2 \mathrm{~mm}$ dCTP, 0.2 mm dGTP, 0.2 mm dTTP, and 2.5 U TaqDNA polymerase (Perkin Elmer, San Jose, California) and $20 \mathrm{pm}$ each of both the sense and the antisense primers. To allow a quantitative determination of relative gene expression levels, the cDNA content of the samples was normalized, and the linear range of amplification was determined for each primer set. For each experiment, the housekeeping gene GAPDH was amplified with 20 to 30 cycles to normalize the cDNA content of the samples. Equal cDNA amounts were subsequently used for the amplification of specific genes. The amplification was performed at $94^{\circ} \mathrm{C}(1$ minute), $60^{\circ} \mathrm{C}$ ( 2 minutes), and $72^{\circ} \mathrm{C}$ (3 minutes) for 24 to 30 cycles. The specific primers for human and murine genes studied by RT-PCR are listed in Tables 1 and 3 , respectively. For quantitative determination of the relative gene expression levels, the $20-\mu$ l samples were collected during PCR after the completion of three different cycle numbers in a linear range. The amplicons were analyzed on a $2 \%$ Sea Kem LE agarose gel (FMC, Riceland, Maine) stained with ethidium bromide. Pictures of the bands were taken using a digital imaging system (Alpha Imager 2000, San Leandro, California). Band intensities were determined by area integration. The experimental samples were always run in parallel with control samples. In each experiment, the relative gene expression level was determined after at least two different cycle numbers in a linear range and then averaged. To standardize the analysis, the results were expressed as ratio of the gene expression level in an experimental sample compared with that in a control sample. To obtain this ratio, the intensity of the band in the experimental sample was divided by the value obtained in the control sample, and the results from three independent experiments were averaged. Therefore, the gene expression ratio in the control samples is always equal to 1. Negative controls included (a) omission of the RT step and (b) blank samples consisting of reaction mixtures without RNA, both of which were run in parallel with experimental samples.

\section{WB Assay}

Proteins were isolated from the phenol ethanol supernatant by adding $1.5 \mathrm{ml}$ of isopropyl alcohol per $1 \mathrm{ml}$ of TRIzol Reagent used for the initial homogenization of fibroblast cultures. Protein pellets were washed three times with $2 \mathrm{ml}$ of $0.3 \mathrm{M}$ guanidine hydrochloride in $95 \%$ ethanol and then one time with $2 \mathrm{ml}$ of $95 \%$ ethanol. The pellets were dissolved in sample application buffer $(1.0 \mathrm{ml}$ of $0.5 \mathrm{M}$ Tris- $\mathrm{HCl}$ [pH 6.8], $1.9 \mathrm{gm}$ of ultra pure urea, and 10\% SDS (both from Fisher Scientific, Tustin, California)]. Proteins were separated in gradient $4 \%$ to $15 \%$ SDS-PAGE, electroblotted onto a 0.2- $\mu \mathrm{m}$ nitrocellulose membrane (Bio-Rad, Hercules, California), and blocked overnight at $4^{\circ} \mathrm{C}$ in the blocking buffer consisting of $5 \%$ nonfat dried milk in $0.1 \%$ (v/v) Tween 20 (Sigma Chemical Company), $25 \mathrm{~mm}$ Tris- $\mathrm{HCl}(\mathrm{pH} \mathrm{8}), 125 \mathrm{~mm} \mathrm{NaCl}$, and $0.05 \%$ sodium azide. The primary Abs were diluted in the blocking buffer and incubated for 1 hour at room temperature. The specificity and the dilutions of primary Abs used and their sources are listed in Table 2. The secondary Abs (donkey anti-rabbit or sheep antimouse Ig labeled with horseradish peroxidase; Amersham Pharmacia Biotech, Inc., Piscataway, New Jersey) were diluted 1:3000 in the blocking buffer lacking sodium azide and applied to the membrane for 1 hour at room temperature. The membranes were developed using the ECL + Plus chemiluminescent detection system (Amersham Pharmacia Biotech, Inc.). To visualize $A b$ binding, the membranes were scanned with Fluorlmager/Storm (Molecular Dynamics, Mountain View, California), and the intensity of the bands was analyzed using the ImageQuant software (Molecular Dynamics). The results were standardized by expressing the density of each protein band under investigation in the experimental sample relative to the value determined in the control sample. The ratios obtained in three independent experiments were averaged to obtain the mean value. The specificity of staining was controlled in negative control experiments, in which the antipeptide antiserum was preincubated with the specific peptide used for immunization, or the primary $A b$ was either omitted or replaced with an irrelevant, isotype- and species-matched Ab.

\section{Radioligand Binding Assay}

The nAChR binding studies were performed using the radioligand $\left[{ }^{3} \mathrm{H}\right] \mathrm{Ep}$ with a specific activity of 54.0 
$\mathrm{Ci} / \mathrm{mmol}$ (Amersham Pharmacia Biotech, Inc.) in monolayers of experimental (pre-exposed to Nic) and control (nonexposed) human DF. The cells were seeded into 24-well cell and tissue culture plates (Becton Dickinson, Franklin Lakes, New Jersey) at a density of $2 \times 10^{5}$ DF per well and incubated overnight in a $5 \% \mathrm{CO}_{2}$ incubator at $37^{\circ} \mathrm{C}$, to allow the cells to settle and attach to the dish bottom. Then, the wells were washed to remove nonattached cells, and the monolayers were exposed to FGM containing $10 \mu \mathrm{M}$ Nic alone or in combination with $50 \mu \mathrm{M}$ Mec versus no additions (control). The plates were returned to the $\mathrm{CO}_{2}$ incubator. After 24 hours of incubation, the monolayers were washed thoroughly with PBS, put on ice, and used in a standard whole-cell radioligand binding assay described in detail elsewhere (Arredondo et al, 2001; Buchli et al, 2001). Briefly, 100- $\mu$ l aliquots of $\mathrm{PBS}$ containing increasing concentrations of $\left[{ }^{3} \mathrm{H}\right] \mathrm{Ep}$ from $10^{-15}$ to $10^{-9} \mathrm{M}$ were added to the triplicate wells, and the binding was allowed to reach equilibrium during a 4-hour incubation at $4^{\circ} \mathrm{C}$. The nonspecific binding was determined in the presence of the cold ligand Nic $(300 \mu \mathrm{M})$. The nonbound radioligand was removed by thorough washing with icecold PBS. The monolayers were solubilized in $1 \%$ SDS, the aliquots were mixed with scintillation cocktail, and the radioactivity was measured in an automated scintillation $\beta$-counter (Wallac, Gaithersburg, Maryland). Saturation isotherms were analyzed by nonlinear regression with the Prism software (GraphPad Software, San Diego, California). The results were expressed both per cell and per milligram of cell protein. The protein concentration was determined at the end of each experiment in the replicas of experimental and control monolayers using the Bradford assay (BioRad, Richmond, California).

\section{IF Assay}

Double IF staining experiments were performed as detailed elsewhere (Buchli et al, 1999) with minor modifications. Briefly, 4- to $8-\mu \mathrm{m}$ sections of freshly frozen human neonatal foreskins were fixed for 3 minutes with $3 \%$ fresh depolymerized paraformaldehyde in PBS that contained $7 \%$ sucrose to avoid cell permeabilization and then washed with PBS, air dried, and incubated overnight at $4^{\circ} \mathrm{C}$ with a mixture of primary $\mathrm{Ab}$ (rabbit anti-nAChR subunit-specific $\mathrm{Ab}$ ) and mouse anti-fibroblast Ab 1B10 (Table 2). Excess primary $A b$ was removed by repeated washing, and the specimens were exposed for 1 hour at room temperature to FITC-conjugated anti-rabbit IgG Ab (final dilution 1:100) and a tetramethylrhodamine isothiocyanate-conjugated anti-mouse lgG Ab (Pierce, Rockford, Illinois) (final dilution 1:50). All Abs were diluted in PBS (pH 7.4). The IF images were acquired using a computer-linked, video-monitored Axiovert 135 fluorescence microscope (Carl Zeiss Inc., Thornwood, New York) equipped with a CCD video camera (Photon Technology International, Monmouth Junction, New Jersey) and analyzed using an image analysis software package purchased from Scanalytics
(Fairfax, Virginia). The specificity of Ab binding in IF experiments was demonstrated by omitting the primary $A b$ or by replacing the primary $A b$ with an irrelevant $A b$ of the same isotype and species as the primary $\mathrm{Ab}$.

\section{AsOs Assay}

The phosphorothioated and FITC-tagged AsOs and the phosphorothioated, equally sized sense oligonucleotide (control) were commercially synthesized by Operon (Alameda, California). The sequences used in this study are shown in Table 4. Each was designed to contain comparable amounts of pyrimidines and purines. The uniqueness of the sequences targeted by each of the AsOs was determined by comparing the targeted sequence against sequences found in GenBank and other databases using BLAST (Altschul et al, 1990). Following the protocol provided by the manufacturer, AsOs were mixed with LipofectAMINE PLUS reagent (Gibco BRL) and transfected into second passage human foreskin DF grown in a standard 6 -well tissue culture plate in $2.0 \mathrm{ml}$ of FGM. Each experimental culture received $20 \mathrm{~nm}$ of AsOs, and the control cultures received the same dose of control (sense) oligonucleotide, diluted in FGM. The transfected cells were incubated at $37^{\circ} \mathrm{C}$ in a $5 \% \mathrm{CO}_{2}$ incubator for 72 hours, after which the transfected cells were harvested for protein purification for WB analysis of the levels of cell cycle regulator expression.

\section{Statistical Analysis}

The results of quantitative assays were analyzed using the Graph-Pad Software Prism to obtain mean \pm SD. Statistical significance was calculated using Student's test. A $p$ value less than 0.05 indicated a significant difference.

\section{Acknowledgements}

We are grateful to Ms. Arlene D. Gonzales, Biology \& Biotechnology Research Program, Lawrence Livermore National Laboratory, Livermore, California, for help with experiments with antisense oligonucleotides. We thank Ms. Tamara E. Rees for her help with illustrations.

\section{References}

Aizen E and Gilhar A (2001). Smoking effect on skin wrinkling in the aged population. Int J Dermatol 40:431-433.

Altschul SF, Gish W, Miller W, Myers EW, and Lipman DJ (1990). Basic local alignment search tool. J Mol Biol 215:403410.

Arredondo J, Nguyen VT, Chernyavsky Al, Jolkovsky DL, Pinkerton KE, and Grando SA (2001). A receptor-mediated mechanism of nicotine toxicity in oral keratinocytes. Lab Invest 81:1653-1668.

Ashcroft GS, Horan MA, and Ferguson MW (1997a). Aging is associated with reduced deposition of specific extracellular matrix components, an upregulation of angiogenesis, and an 
altered inflammatory response in a murine incisional wound healing model. J Invest Dermatol 108:430-437.

Ashcroft GS, Horan MA, Herrick SE, Tarnuzzer RW, Schultz GS, and Ferguson MWJ (1997b). Age-related differences in the temporal and spatial regulation of matrix metalloproteinases (MMPs) in normal skin and acute cutaneous wounds of healthy humans. Cell Tissue Res 290:581-591.

Bartek J, Staskova Z, Draetta G, and Lukas J (1993). Molecular pathology of the cell cycle in human cancer cells. Stem Cells 11(Suppl 1):51-58.

Benowitz NL (1986). Clinical pharmacology of nicotine. Ann Rev Med 37:21-32

Benowitz NL (1997). Systemic absorption and effects of nicotine from smokeless tobacco. Adv Dent Res 11:336-341.

Benowitz NL and Gourlay SG (1997). Cardiovascular toxicity of nicotine: Implications for nicotine replacement therapy. J Am Coll Cardiol 29:1422-1431.

Bering B, Moises HW, and Muller WE (1987). Muscarinic cholinergic receptors on intact human lymphocytes: Properties and subclass characterization. Biol Psychiatry 22:14511458.

Buchli R, Ndoye A, Arredondo J, Webber RJ, and Grando SA (2001). Identification and characterization of muscarinic acetylcholine receptor subtypes expressed in human skin melanocytes. Mol Cell Biochem 228:57-72.

Buchli R, Ndoye A, Rodriguez JG, Zia S, Webber RJ, and Grando SA (1999). Human skin fibroblasts express m2, m4, and $\mathrm{m} 5$ subtypes of muscarinic acetylcholine receptors. J Cell Biochem 74:264-277.

Carty CS, Soloway PD, Kayastha S, Bauer J, Marsan B, Ricotta JJ, and Dryjski M (1996). Nicotine and cotinine stimulate secretion of basic fibroblast growth factor and affect expression of matrix metalloproteinases in cultured human smooth muscle cells. J Vasc Surg 24:27-35.

Chamson A, Frey J, and Hivert M (1982). Effects of tobacco smoke extracts on collagen biosynthesis by fibroblast cell cultures. J Toxicol Environ Health 9:921-932.

Checchi L, Ciapetti G, Monaco G, and Ori G (1999). The effects of nicotine and age on replication and viability of human gingival fibroblasts in vitro. J Clin Periodontol 26:636642.

Chomczynski P and Sacchi N (1987). Single-step method of RNA isolation by acid guanidinium thiocyanate-phenolchloroform extraction. Anal Biochem 162:156-159.

Elgoyhen AB, Vetter DE, Katz E, Rothlin CV, Heinemann SF, and Boulter $\mathrm{J}$ (2001). $\alpha 10$ : A determinant of nicotinic cholinergic receptor function in mammalian vestibular and cochlear mechanosensory hair cells. Proc Natl Acad Sci USA 98: 3501-3506.

Ernster VL, Grady D, Miike R, Black D, Selby J, and Kerlikowske K (1995). Facial wrinkling in men and women, by smoking status. Am J Public Health 85:78-82.

Evinger MJ, Ernsberger P, Regunathan S, Joh TH, and Reis DJ (1994). A single transmitter regulates gene expression through two separate mechanisms: Cholinergic regulation of phenylethanolamine $\mathrm{N}$-methyltransferase mRNA via nicotinic and muscarinic pathways. J Neurosci 14:2106-2116.

Falugi C, Pieroni M, and Moretti E (1993). Cholinergic molecules and sperm functions. J Submicr Cytol Pathol 25:63-69.
Flores CM, Rogers SW, Pabreza LA, Wolfe BB, and Kellar KJ (1992). A subtype of nicotinic cholinergic receptor in rat brain is composed of $\alpha 4$ and $\beta 2$ subunits and is up-regulated by chronic nicotine treatment. Mol Pharmacol 41:31-37.

Frances C (1998). Smoker's wrinkles: Epidemiological and pathogenic considerations. Clin Dermatol 16:565-570.

Frick WG and Seals RR Jr (1994). Smoking and wound healing: A review. Texas Dent J 111:21-23.

Gerdes J (1990). Ki-67 and other proliferation markers useful for immunohistological diagnostic and prognostic evaluations in human malignancies. Semin Cancer Biol 1:199-206.

Gerzanich V, Wang F, Kuryatov A, and Lindstrom J (1998). $\alpha 5$ subunit alters desensitization, pharmacology, $\mathrm{Ca}^{++}$permeability and $\mathrm{Ca}^{++}$modulation of human neuronal $\alpha 3$ nicotinic receptors. J Pharmacol Exp Ther 286:311-320.

Giannopoulou C, Geinoz A, and Cimasoni G (1999). Effects of nicotine on periodontal ligament fibroblasts in vitro. J Clin Periodontol 26:49-55.

Grando SA (1997). Biological functions of keratinocyte cholinergic receptors. J Invest Dermatol Symp Proc 2:41-48.

Grando SA (2001). Receptor-mediated action of nicotine in human skin. Int J Dermatol 40:691-693.

Grando SA, Horton RM, Mauro TM, Kist DA, Lee TX, and Dah MV (1996). Activation of keratinocyte nicotinic cholinergic receptors stimulates calcium influx and enhances cell differentiation. J Invest Dermatol 107:412-418.

Grando SA, Horton RM, Pereira EFR, Diethelm-Okita BM, George PM, Albuquerque EX, and Conti-Fine BM (1995). A nicotinic acetylcholine receptor regulating cell adhesion and motility is expressed in human keratinocytes. J Invest Dermatol 105:774-781.

Grinnell F (1994). Fibroblasts, myofibroblasts, and wound contraction. J Cell Biol 124:401-404.

Haber J (1994). Cigarette smoking: A major risk factor for periodontitis. Compendium 15:1002,1004-1008.

Hall LL, Buchli R, Ndoye A, Webber RJ, and Grando SA (2000). Identification of nicotinic receptors in human skin fibroblasts and study of their role in mediating tobaccorelated skin disease (Abstract). J Invest Dermatol 114:802.

Hanes PJ, Schuster GS, and Lubas S (1991). Binding, uptake, and release of nicotine by human gingival fibroblasts. J Periodontol 62:147-152.

Heeschen C, Jang JJ, Weis M, Pathak A, Kaji S, Hu RS, Tsao PS, Johnson FL, and Cooke JP (2001). Nicotine stimulates angiogenesis and promotes tumor growth and atherosclerosis. Nat Med 7:833-839.

Hill P, Haley NJ, and Wynder EL (1983). Cigarette smoking: Carboxyhemoglobin, plasma nicotine, cotinine and thiocyanate vs self-reported smoking data and cardiovascular disease. J Chronic Dis 36:439-449.

Ishii $\mathrm{T}$, Matsuse $\mathrm{T}$, Igarashi $\mathrm{H}$, Masuda $\mathrm{M}$, Teramoto $\mathrm{S}$, and Ouchi $Y$ (2001). Tobacco smoke reduces viability in human lung fibroblasts: Protective effect of glutathione S-transferase P1. Am J Physiol Lung Cell Mol Physiol 280: L1189-L1195.

James JA, Sayers NM, Drucker DB, and Hull PS (1999). Effects of tobacco products on the attachment and growth of periodontal ligament fibroblasts. J Periodontol 70:518-525. 
James JR and Nordberg A (1995). Genetic and environmental aspects of the role of nicotinic receptors in neurodegenerative disorders: Emphasis on Alzheimer's disease and Parkinson's disease. Behav Genet 25:149-159.

Joad JP, Ji C, Kott KS, Bric JM, and Pinkerton KE (1995). In utero and postnatal effects of sidestream cigarette smoke exposure on lung function, hyperresponsiveness, and neuroendocrine cells in rats. Toxicol Appl Pharmacol 132:63-71.

Joad JP, Pinkerton KE, and Bric JM (1993). Effects of sidestream smoke exposure and age on pulmonary function and airway reactivity in developing rats. Pediatr Pulmonol 16:281-288.

Kadunce DP, Burr R, Gress R, Kanner R, Lyon JL, and Zone JJ (1991). Cigarette smoking: Risk factor for premature facial wrinkling. Ann Intern Med 114:840-844.

Kahari VM and Saarialho-Kere U (1997). Matrix metalloproteinases in skin. Exp Dermatol 6:199-213.

Klapproth H, Reinheimer T, Metzen J, Munch M, Bittinger F, Kirkpatrick CJ, Hohle KD, Schemann M, Racke K, and Wessler I (1997). Non-neuronal acetylcholine, a signalling molecule synthezised by surface cells of rat and man. Naunyn-Schmiedebergs Arch Pharmacol 355:515-523.

Kletsas D, Pratsinis H, Zervolea I, Handris P, Sevaslidou E, Ottaviani E, and Stathakos D (2000). Fibroblast responses to exogenous and autocrine growth factors relevant to tissue repair: The effect of aging. Ann NY Acad Sci 908:155-166.

Koh JS, Kang H, Choi SW, and Kim HO (2002). Cigarette smoking associated with premature facial wrinkling: Image analysis of facial skin replicas. Int J Dermatol 41:21-27.

Konno S, Oronsky BT, Semproni AR, and Wu JM (1991). The effect of nicotine on cell proliferation and synthesis of secreted proteins in BALB/C 3T3 cells. Biochem Int 25:7-17.

Kwiatkowski TC, Hanley EN Jr, and Ramp WK (1996). Cigarette smoking and its orthopedic consequences. Am J Orthoped 25:590-597.

Kwon OS, Chung JH, Cho KH, Suh DH, Park KC, Kim KH, and Eun HE (1999). Nicotine-enhanced epithelial differentiation in reconstructed human oral mucosa in vitro. Skin Pharmacol Appl Skin Physiol 12:227-234.

Lahmann C, Bergemann J, Harrison G, and Young AR (2001a). Matrix metalloproteinase-1 and skin ageing in smokers. Lancet 357:935-936.

Lahmann C, Young AR, Wittern KP, and Bergemann J (2001b). Induction of mRNA for matrix metalloproteinase 1 and tissue inhibitor of metalloproteinases 1 in human skin in vivo by solar simulated radiation. Photochem Photobiol 73: 657-663.

Lahmouzi J, Simain-Sato F, Defresne MP, De Pauw MC, Heinen E, Grisar T, Legros JJ, and Legrand R (2000). Effect of nicotine on rat gingival fibroblasts in vitro. Connect Tissue Res 41:69-80.

Lindell G, Farnebo LO, Chen D, Nexo E, Rask Madsen J, Bukhave K, and Graffner H (1993). Acute effects of smoking during modified sham feeding in duodenal ulcer patients: An analysis of nicotine acid secretion, gastrin, catecholamines, epidermal growth factor, prostaglandin E2, and bile acids. Scand J Gastroenterol 28:487-494.

Lindenboim L, Pinkas-Kramarski R, Sokolovsky M, and Stein $R$ (1995). Activation of muscarinic receptors inhibits apoptosis in PC12M1 cells. J Neurochem 64:2491-2499.
Macklin KD, Maus AD, Pereira EF, Albuquerque EX, and Conti-Fine BM (1998). Human vascular endothelial cells express functional nicotinic acetylcholine receptors. J Pharmacol Exp Ther 287:435-439.

Maneckjee R and Minna JD (1994). Opioids induce while nicotine suppresses apoptosis in human lung cancer cells. Cell Growth Differ 5:1033-1040.

Maus ADJ, Pereira EFR, Karachunski PI, Horton RM, Navaneetham D, Macklin K, Cortes WS, Albuquerque EX, and Conti-Fine BM (1998). Human and rodent bronchial epithelial cells express functional nicotinic acetylcholine receptors. Mol Pharmacol 54:779-788.

Miao H, Liu C, Bishop K, Gong ZH, Nordberg A, and Zhang $X$ (1998). Nicotine exposure during a critical period of development leads to persistent changes in nicotinic acetylcholine receptors of adult rat brain. J Neurochem 70:752-762.

Mooney SM and Miller MW (2001). Effects of prenatal exposure to ethanol on the expression of bcl-2, bax and caspase 3 in the developing rat cerebral cortex and thalamus. Brain Res 911:71-81.

Morimoto Y, Tsuda T, Nakamura H, Hori H, Yamato $H$, Nagata N, Higashi T, Kido M, and Tanaka I (1997). Expression of matrix metalloproteinases, tissue inhibitors of metalloproteinases, and extracellular matrix mRNA following exposure to mineral fibers and cigarette smoke in vivo. Environ Health Perspect 105(Suppl 5):1247-1251.

Mulle C, Choquet D, Korn H, and Changeux JP (1992). Calcium influx through nicotinic receptor in rat central neurons: Its relevance to cellular regulation. Neuron 8:135143.

Nakamura Y, Romberger DJ, Tate L, Ertl RF, Kawamoto M, Adachi Y, Mio T, Sisson JH, Spurzem JR, and Rennard SI (1995). Cigarette smoke inhibits lung fibroblast proliferation and chemotaxis. Am J Resp Crit Care Med 151:1497-1503.

Nguyen VT, Hall LL, Gallacher G, Ndoye A, Jolkovsky DL, Webber RJ, Buchli R, and Grando SA (2000). Choline acetyltransferase, acetylcholinesterase, and nicotinic acetylcholine receptors of human gingival and esophageal epithelia. J Dent Res 79:939-949.

Odland GF (1991). Structure of the skin. In: LA Goldsmith, editor. Physiology, biochemistry, and molecular biology of the skin. New York: Oxford University Press, 3-62.

Peacock ME, Sutherland DE, Schuster GS, Brennan WA, O'Neal RB, Strong SL, and Van Dyke TE (1993). The effect of nicotine on reproduction and attachment of human gingival fibroblasts in vitro. J Periodontol 64:658-665.

Pinkas-Kramarski R, Stein R, Lindenboim L, and Sokolovsky $M$ (1992). Growth factor-like effects mediated by muscarinic receptors in PC12M1 cells. J Neurochem 59:2158-2166.

Qandil R, Sandhu HS, and Matthews DC (1997). Tobacco smoking and periodontal diseases. J Can Dent Assoc 63: 187- 192,194-185.

Raitio A, Risteli J, Vahakangas K, and Oikarinen A (2000). Evidence of disturbed collagen metabolism in smokers: A possible etiologic factor for accelerated skin aging. J Invest Dermatol 114:822.

Raitio A, Vahakangas K, Haapasaari K-M, Risteli J, and Oikarinen A (1999). Smoking downregulates collagen synthesis in skin. J Invest Dermatol 113:452. 
Reiser K, McGee C, Rucker R, and McDonald R (1995). Effects of aging and caloric restriction on extracellular matrix biosynthesis in a model of injury repair in rats. J Gerontol A Biol Sci Med Sci 50A:B40-47.

Richman DP and Arnason BG (1979). Nicotinic acetylcholine receptor: Evidence for a functionally distinct receptor on human lymphocytes. Proc Natl Acad Sci USA 76:4632-4635.

Rota MT, Poggi P, Baratta L, Gaeta E, Boratto R, and Tazzi A (1999). Tobacco smoke in the development and therapy of periodontal disease: Progress and questions. Bull Group Int Rech Sci Stomatol Odontol 41:116-122.

Russell MA, Jarvis M, lyer R, and Feyerabend C (1980). Relation of nicotine yield of cigarettes to blood nicotine concentrations in smokers. Br Med J 280:972-976.

Russell MA, Jarvis MJ, Devitt G, and Feyerabend C (1981). Nicotine intake by snuff users. Br Med J 283:814-817.

Sekhon HS, Jia Y, Raab R, Kuryatov A, Pankow JF, Whitsett JA, Lindstrom J, and Spindel ER (1999). Prenatal nicotine increases pulmonary $\alpha 7$ nicotinic receptor expression and alters fetal lung development in monkeys. J Clin Invest 103:637-647.

Sekhon HS, Keller JA, Proskocil BJ, Martin EL, and Spindel ER (2002). Maternal nicotine exposure upregulates collagen gene expression in fetal monkey lung: Association with $\alpha 7$ nicotinic acetylcholine receptors. Am J Respir Cell Mol Biol 26:31-41.

Silverstein P (1992). Smoking and wound healing. Am J Med 93:22S-24S

Steinbach JH (1990). Mechanism of action of the nicotinic acetylcholine receptor. In: G Bock and J Marsh, editors. The biology of nicotine dependence (Meeting, London, England, UK, November 7-9, 1989). New York: John Wiley and Sons, Ltd., 53-61.

Stewart TA and Forrester IT (1978). Identification of a cholinergic receptor in ram spermatozoa. Biol Reprod 19:965-970.

Takeda K, Gosiewska A, and Peterkofsky B (1992). Similar, but not identical, modulation of expression of extracellular matrix components during in vitro and in vivo aging of human skin fibroblasts. J Cell Physiol 153:450-459.

Theilig C, Bernd A, Ramirez-Bosca A, Gormar FF, BereiterHahn J, Keller-Stanislawski B, Sewell AC, Rietbrock N, and Holzmann H (1994). Reactions of human keratinocytes in vitro after application of nicotine. Skin Pharmacol 7:307-315.

Tipton DA and Dabbous MK (1995). Effects of nicotine on proliferation and extracellular matrix production of human gingival fibroblasts in vitro. J Periodontol 66:1056-1064.

Tomek RJ, Rimar S, and Eghbali-Webb M (1994). Nicotine regulates collagen gene expression, collagenase activity, and DNA synthesis in cultured cardiac fibroblasts. Mol Cell Biochem 136:97-103.
Tomicic MT and Kaina B (2001). Hamster Bcl-2 protein is cleaved in vitro and in cells by caspase- 9 and caspase-3. Biochem Biophys Res Commun 281:404-408.

Waseem NH and Lane DP (1990). Monoclonal antibody analysis of the proliferating cell nuclear antigen (PCNA): Structural conservation and the detection of a nucleolar form. J Cell Sci 96:121-129.

West MD (1994). The cellular and molecular biology of skin aging. Arch Dermatol 130:87-95.

Wokalek H and Ruh H (1991). Time course of wound healing. J Biomater Appl 5:337-362.

Xu W, Gelber S, Orr-Urtreger A, Armstrong D, Lewis RA, Ou CN, Patrick J, Role L, De Biasi M, and Beaudet AL (1999). Megacystis, mydriasis, and ion channel defect in mice lacking the $\alpha 3$ neuronal nicotinic acetylcholine receptor. Proc Natl Acad Sci USA 96:5746-5751.

Yan G-M, Lin S-Z, Irwin RP, and Paul SM (1995). Activation of muscarinic cholinergic receptors blocks apoptosis of cultured cerebellar granule neurons. Mol Pharmacol 47:248257.

Yin L, Morita A, and Tsuji T (2000). Alterations of extracellular matrix induced by tobacco smoke extract. Arch Dermatol Res 292:188-194.

Yin L, Morita A, and Tsuji T (2001). Skin aging induced by ultraviolet exposure and tobacco smoking: Evidence from epidemiological and molecular studies. Photodermatol Photoimmunol Photomed 17:178-183.

Young RJ and Laing JC (1991). The binding characteristics of cholinergic sites in rabbit spermatozoa. Mol Reprod Dev 28:55-61.

Zevin S, Gourlay SG, and Benowitz NL (1998). Clinical pharmacology of nicotine. Clin Dermatol 16:557-564.

Zhang S, Day I, and Ye S (2001a). Nicotine induced changes in gene expression by human coronary artery endothelial cells. Atherosclerosis 154:277-283.

Zhang S, Day IN, and Ye S (2001b). Microarray analysis of nicotine-induced changes in gene expression in endothelial cells. Physiol Genomics 5:187-192.

Zia S, Ndoye A, Lee TX, Webber RJ, and Grando SA (2000). Receptor-mediated inhibition of keratinocyte migration by nicotine involves modulations of calcium influx and intracellular concentration. J Pharmacol Exp Ther 293:973-981.

Zia S, Ndoye A, Nguyen VT, and Grando SA (1997). Nicotine enhances expression of the $\alpha 3, \alpha 4, \alpha 5$, and $\alpha 7$ nicotinic receptors modulating calcium metabolism and regulating adhesion and motility of respiratory epithelial cells. Res Commun Mol Pathol Pharmacol 97:243-262. 